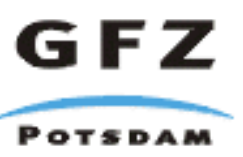

Originally published as:

Lindh, A., Andersson, U. B., Lundqvist, T., Claesson, S. (2001): Evidence of crustal contamination of mafic rocks associated with rapakivi rocks: an example from the Nordingrå complex, Central Sweden. - Geological Magazine, 138, 4, 371-386.

DOI: $10.1017 / \mathrm{S} 0016756801005672$ 


\title{
Evidence of crustal contamination of mafic rocks associated with rapakivi rocks: an example from the Nordingrå complex, Central Sweden
}

\author{
ANDERS LINDH*, ULF BERTIL ANDERSSON†, THOMAS LUNDQVIST: \\ \& STEFAN CLAESSON§ \\ *Geological Department, Sölvegatan 13, SE-223 62 Lund, Sweden \\ $\uparrow$ Department of Earth Sciences, Villavägen 16, SE-752 36 Uppsala, Sweden \\ \$Geological Survey of Sweden, Box 670, SE-751 28 Uppsala, Sweden \\ $\S$ Laboratory for Isotope Geology, Swedish Museum of Natural History, Box 50007, SE-104 05 Stockholm, Sweden
}

(Received 4 August 2000; accepted 27 April 2001)

\begin{abstract}
Gabbro and leucogabbro are volumetrically important rocks in the Nordingrå rapakivi complex, East Central Sweden. Plagioclase, ortho- and clinopyroxenes, and olivine dominate the gabbro. Perthitic orthoclase and quartz are interstitial in relation to the major minerals. The present work is based on 232 major-element and a large number of trace element analyses together with 15 whole rock $\mathrm{Sm}-\mathrm{Nd}$ isotope analyses of the Nordingrå gabbroic rocks. $\varepsilon_{\mathrm{Nd}(\mathrm{T})}$ values are negative, -1.1 to -3.2 ; the most negative values come from the gabbro. Most rocks are enriched in iron, some extremely enriched; none represent primitive mantle melts. The range of Mg-numbers is the same in the gabbro and the leucogabbro. Plots of the Ni-content vs. the Mg-number are scattered, but there is a positive correlation between these two parameters. The primary mantle-normalized ratios between similar trace elements are normally strongly different from one. Values larger as well as smaller than one are found for the same ratio in different rocks. The rare earth elements are only weakly fractionated with small Eu anomalies, negative for the gabbros and positive for the leucogabbros. The primary magma of the Nordingrå gabbro-anorthosite is thought to have been derived from a mildly depleted mantle source. Variations in the degree of partial melting of a reasonably homogeneous enriched mantle do not explain the observed chemical evolution. Crystal differentiation can account for some geochemical features, especially the Fe-enrichment. Crustal contamination is required by other characteristics as, for example, the negative $\varepsilon_{\mathrm{N}(\mathrm{T})}$ values and the irregular and sometimes high primary-mantle normalized incompatible trace-element ratios. Al-rich relic material from the formation of the rapakivi granite melt is another source of assimilation. Most probably contaminants are heterogeneous, including undepleted crust (represented, for example, by early Svecofennian and Archaean granitoids), depleted crust (restitic after rapakivi magma extraction), and to some degree the associated rapakivi magma itself. Significant parts of this crust should be Archaean in age.
\end{abstract}

\section{Introduction}

Rapakivi granites and associated mafic rocks occur on all continents. In the Baltic Shield, they form an important rock group. Most of them have intruded into the Palaeoproterozoic Svecofennian rocks; the most easterly massifs, however, were emplaced on the border between the Archaean craton and the Svecofennian Orogen. Figure 1 shows the major massifs of the Shield. In addition, numerous smaller massifs occur scattered in the same general area as the major ones. The massifs show a distinct younging westwards (cf. Fig. 1) from the oldest in southeastern Finland and northern Estonia (c. $1.65-1.61 \mathrm{Ga}$ ) to central Sweden (c. 1.53-1.50 Ga). This belt-like appearance of rapakivi rocks seems to have developed stepwise,

\footnotetext{
* Author for correspondence: anders.lindh@geol.lu.se $\dagger$ Present address: GeoForschungsZentrum, P.B. 4.1, Telegrafenberg, D-14473 Potsdam, Germany
}

where an intermediate (c. $1.59-1.56 \mathrm{Ga})$ belt from the Riga Batholith in the south to the Nordingrå Massif in the north separates the oldest and the youngest rapakivis (cf. Andersson, 1997a). However, the easternmost massifs in Russian Karelia break this simple pattern, since they are $0.1 \mathrm{Ga}$ younger than their nearest neighbours to the west.

The Nordingrå rapakivi massif occurs in East Central Sweden. Lundbohm (1899) and Högbom (1909) first mapped the massif. The most detailed mapping was, however, published a few years later, accompanied by an elaborate description of the rocks (Sobral, 1913). The latest published map is part of the mapping programme of the Geological Survey of Sweden (Lundqvist et al. 1990). These maps are all in good agreement because of good exposure and distinct lithologies in the area. Figure 2 is a simplified compilation of these maps. Granite, gabbro and leucogabbro with associated anorthosite make up the massif together with minor monzonite. Mafic rocks play an 


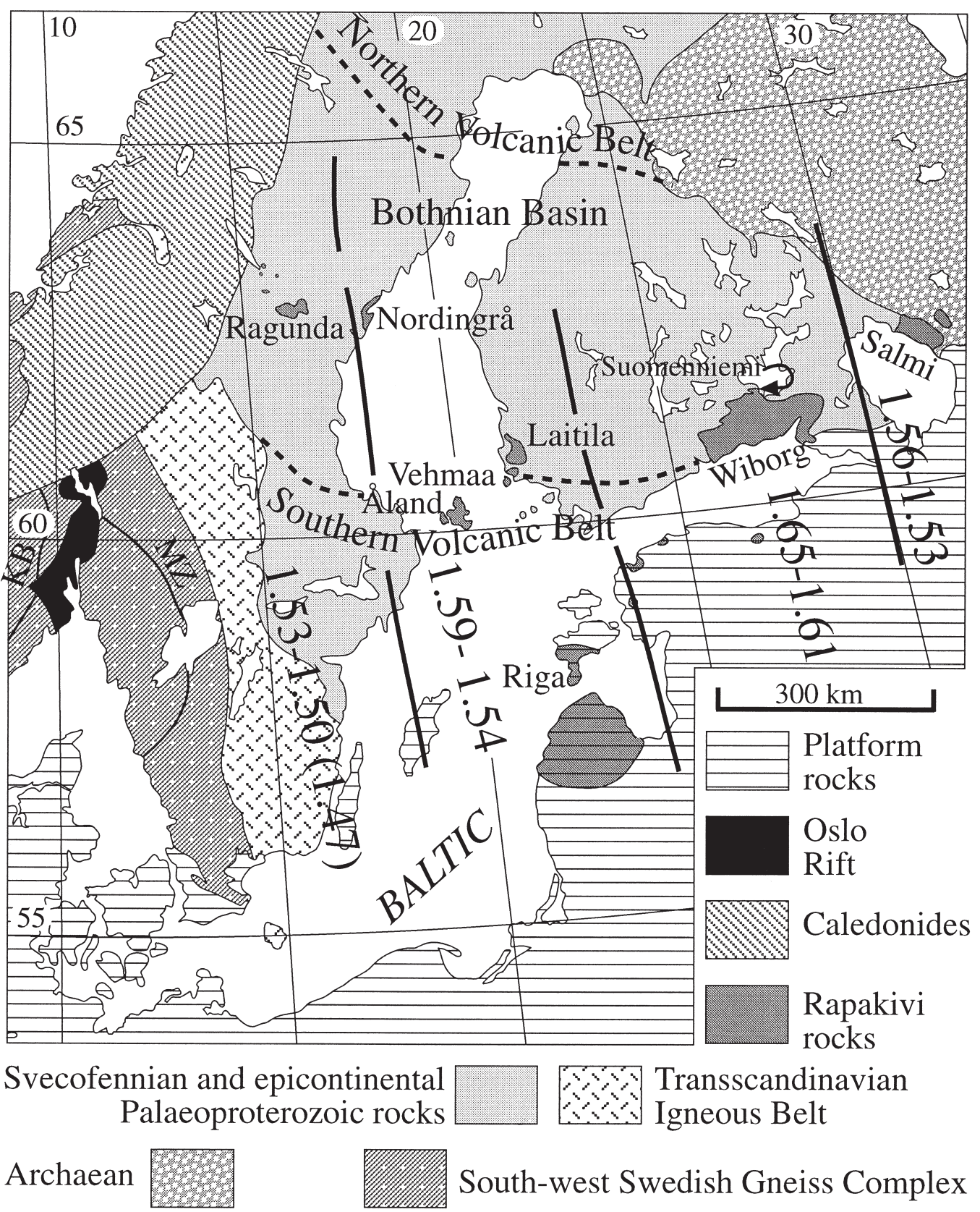

Figure 1. Location map showing the rapakivi massifs of the Baltic Shield and neighbouring parts of the East European Platform. Age provinces are indicated with numbers (in Ga) and heavy lines (after Andersson, 1997a). Some small Swedish and Finnish rapakivi massifs are excluded from the map. The Suomenniemi massif is a satellite to the Wiborg massif. KB Kristiansand-Bang Zone; MZ - Mylonite Zone.

important part. Specific to the Nordingrå massif is its high percentage of outcropping leucogabbro and anorthosite.

According to an age determination on zircons, the intrusion age of the Nordingrå rapakivi granite is $1578 \pm 19 \mathrm{Ma}$ (Welin \& Lundqvist, 1984). This is an upper intercept age obtained from slightly discordant zircon fractions. The same authors also reported a two-point discordia suggesting an identical age for the leucogabbro. More recently, T. Mårtensson (unpub. Masters thesis, Univ. Lund, 1997) reported ages obtained by the single zircon evaporation technique on the Nordingrå granite $(1577 \pm 6 \mathrm{Ma})$ and enclaves in the granite. His results confirm the older data. Efforts to date the granite with the $\mathrm{Rb}-\mathrm{Sr}$ whole rock and separated mineral-whole-rock isochron methods were not successful (Welin \& Lundqvist, 1984). Rocks from the approximate time interval $1.78-1.58 \mathrm{Ga}$, that is, between the late Svecofennian granites and the Nordingrå rapakivi rocks, are unknown in the Nordingrå area. Although some shear zones and faults probably were active during this time, the rapakivi plu- 


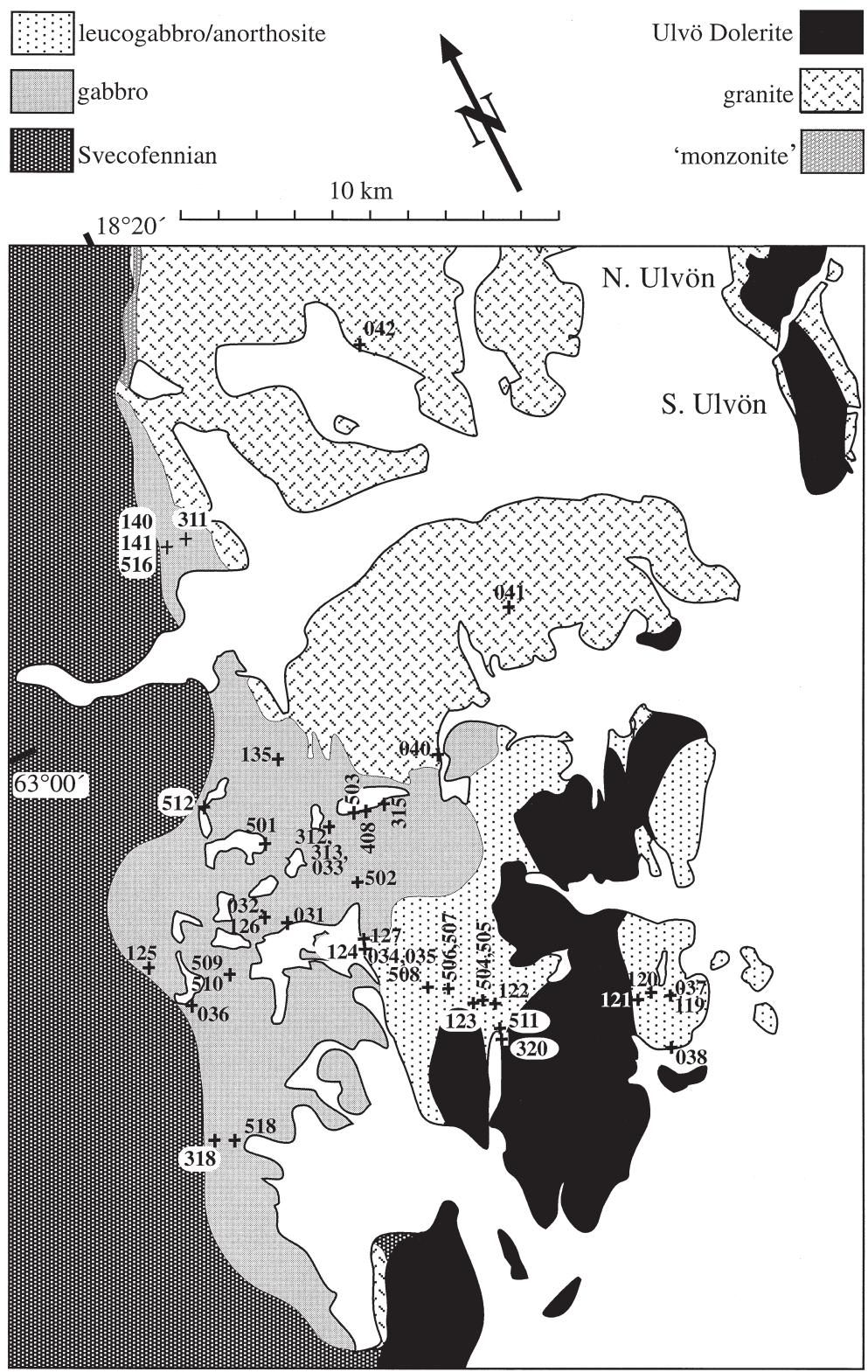

Figure 2. Map of the southern and central parts of the Nordingrå rapakivi massif, simplified after Sobral (1913) and Lundqvist et al. (1990). Sample numbers refer to set 1 of the chemical analyses and the new $\mathrm{Sm}-\mathrm{Nd}$ analyses of rapakivi granites.

tonic rocks are in all evidence anorogenic, emplaced into a cratonized crust. The present paper is devoted to the mafic rocks, especially their chemical composition and the reasons for their chemical variation.

\section{Geological setting and field relations of the Nordingrå rocks}

2.a. Country rocks

All Swedish rapakivi complexes occur in the Svecofennian Bothnian Basin (Hietanen, 1975) dominated by metagreywacke and minor argillite. These have depositional ages between $>1.95$ and $1.87 \mathrm{Ga}$ old (see, e.g. Lundqvist et al. 1990; Claesson et al. 1993; Wasström, 1993; Welin, Christiansson \& Kähr, 1993;
Lundqvist, Vaasjoki \& Persson, 1998). An early generation of calc-alkaline granitoids (intrusion ages, mainly $1.89-1.85 \mathrm{Ga}$; early Svecofennian), dominated by granodiorite and tonalite and two younger generations $(1.83-1.78 \mathrm{Ga})$ of granites intrude the metasediments; the first $(1.82-1.80 \mathrm{Ga})$ comprises typically S-granites, and the second (1.80-1.77 Ga) dominantly I-type (see, e.g. Skiöld, 1988; Skiöld et al. 1993; Romer \& Smeds, 1994; Claesson \& Lundqvist, 1995; Öhlander \& Romer, 1996).

The metamorphic grade in the Bothnian Basin varies. Typically, rocks are characterized by low-pressure upper greenschist to upper amphibolite facies. Abundant migmatites occur in the high-grade areas (Lundqvist et al. 1990). The Nordingrå massif is 
emplaced into a low-grade area. Thermal effects related to the Nordingrå rapakivi rocks have been observed in a narrow zone along the western contact of the massif and in wall-rock xenoliths. Cordierite and hypersthene are formed in xenoliths of metagreywacke, and hypersthene is most prominent in metabasalt xenoliths. A younger dolerite sill is intruded into the Nordingrå rocks (cf. Fig. 2)

\section{2.b. The Nordingrå rocks}

Three rock types form the major constituents of the Nordingrå massif: granite, gabbro and leucogabbro (cf. Fig. 2). The granite occupies the northern parts, whereas in the south the massif is composed of gabbro in the west and leucogabbro in the east. Results from gravimetric surveys along NW-SE and E-W profiles have revealed a positive gravity anomaly in the granite area. This has led H. Henkel to suggest that the granite forms a $1 \mathrm{~km}$ thick sheet on top of the gabbro (see Lundqvist et al. 1990 for details). The gravimetric data further indicate that the leucogabbro forms an approximately equally thick sheet on top of $c .5 \mathrm{~km}$ of gabbro. In the west, the contact between gabbro and country rocks dips westwards below the metasediments.

The Nordingra granite dominates the exposed surface of the massif. Xenoliths of leucogabbro in the granite and dykes of granite in the leucogabbro indicate that the granite is the younger. Mingled contacts and monzonitic hybrids in contact zones suggest that at least locally the granite and the gabbro were liquid simultaneously. Generally, the granite seems to have remained above its solidus longer than the gabbro.

The Nordingrå granite is red or greyish red, rarely grey and typically contains tabular, $0.5-2 \mathrm{~cm}$ long $\mathrm{K}$-feldspar megacrysts embedded in a fine-grained or finely medium-grained, partly granophyric matrix. Lundqvist et al. (1990) and Lindh \& Johansson (1996) give more petrographic data. It is an A-type granite with the extremely low Mg-numbers typical of rapakivi granites. No evolved varieties occur; $\mathrm{Rb} / \mathrm{Ba}$ ratios are low, rare earth element (REE) patterns are gently negatively sloping with pronounced but not very deep negative Eu-anomalies. An origin by melting of early Svecofennian granitoids is consistent with both the chemical and the $\mathrm{Sm}-\mathrm{Nd}$ isotope composition (Lindh \& Johansson, 1996).

Gabbro and leucogabbro are spatially intimately related. In outcrop, the gabbro sometimes forms dykes in, or brecciates, the leucogabbro. Enclaves of true anorthosite and of rare gabbro-like rocks occur in the normal, grey leucogabbro. These facts, together with abundant evidence of contacts between different gabbro types (coarse-, medium- and fine-grained), indicate a close co-magmatic relation among gabbro, leucogabbro and anorthosite, and suggest a multiple intrusion mechanism. The leucogabbro with minor anorthosite occupies an easterly position within the Nordingrå massif. Gravimetric investigations suggest that the leucogabbro overlies the gabbro. The contacts between gabbro and leucogabbro are mostly irregular. At a number of localities, the gabbro displays rhythmical layering and lamination. G. Lundqvist (unpub. FL-thesis, Univ. Gothenburg, 1976) could not demonstrate any consistency in the orientation of this layering.

\section{Petrographic description of the gabbro and leucogabbro}

The gabbro is dark grey, usually medium- or fine-grained but sometimes coarse-grained, the latter with a tendency to weather to gravel. A fine-grained quartz-albite rock occurs as dykes. The leucogabbro is a coarse-grained rock with a plagioclase content between approximately 70 and $90 \%$. Rocks with higher plagioclase contents are referred to as anorthosite; such rocks make up about $20 \%$ of the total anorthosite + leucogabbro volume. Extremely feldspar-rich, white anorthosite varieties occur as enclaves with diameters of up to some tens of metres in 'normal' leucogabbro or gabbro.

Modal and mineral chemical data are partly taken from G. Lundqvist (unpub. FL-thesis, Univ. Gothenburg, 1976) and Lundqvist et al. (1990). The modal composition of the gabbro is dominated by normally zoned plagioclase $\left(\mathrm{An}_{30-60}\right)$. In porphyritic varieties, this mineral occurs as crystals several centimetres in size in addition to matrix plagioclase. It should be noted that some 'porphyritic' gabbros evidently formed by disintegration from enclaves of leucogabbro. In such cases, scattered plagioclase crystals occur in the gabbro close to the enclaves. Olivine $\left(\mathrm{Fo}_{10-50}\right)$ is a normal constituent of the gabbro, but the abundance varies greatly. Reaction rims of orthopyroxene on olivine occur. Iddingsite, serpentine and magnetite are secondary minerals after olivine. Orthopyroxene $\left(\mathrm{En}_{25-60}\right)$ and clinopyroxene $\left(\mathrm{Di}_{30-70}\right)$ occur in the gabbro; Ca-poor pyroxene dominates. The two pyroxenes form discrete crystals as well as lamellar, drop-like or more irregular intergrowths with each other. When clinopyroxene is the host, the intergrowth tends to be finely lamellar.

Small amounts of reddish brown biotite, ilmenite and magnetite occur in the gabbro. Magnetite is usually subordinate to ilmenite and only rarely contains ilmenite lamellae. Scattered grains of pyrrhotite, chalcopyrite, pyrite and cubanite also occur.

Perthitic orthoclase and quartz are interstitial minerals. Their contents may be raised in schlieren in the gabbro. This leads to monzogabbroic and monzodioritic compositions. A high content of K-feldspar and quartz, at times accompanied by hornblende, calcite, epidote and prehnite, is typical for some reddish, pegmatoid or granitoid dykes and schlieren in the gabbro.

The leucogabbro is coarser-grained than the gabbro. Plagioclase crystals are normally $1-4 \mathrm{~cm}$ in length. 
Occasionally larger crystals exist, attaining diameters up to several decimetres. Very coarse-grained (crystals up to a decimetre in size) pegmatoid bodies occur within the leucogabbro. In the leucogabbro, the compositional range of the plagioclase is $\mathrm{An}_{48-67}$, although typically $\mathrm{An}_{60-65}$ and thus slightly more calcic than in the gabbro. A weak zoning is sometimes observed. Bluish or greenish, labradorizing cores of the crystals are found at some localities. Needle-shaped microlites of ilmenite and probably also of magnetite occur as inclusions. Secondary alteration to sericite, prehnite, epidote and calcite is rather common in the plagioclase. This type of alteration affects particularly some varieties with a high content of interstitial K-feldspar. These rocks have a characteristic pinkish-greenish colour.

The mafic minerals of the leucogabbro are mainly a uralitic hornblende, which more or less completely replaces former pyroxenes, clinopyroxene $\left(\mathrm{Di}_{60}\right)$, olivine, reddish brown biotite and opaque minerals. In the uralite, orthopyroxene may occur among the pyroxene relics. Olivine forms small rounded crystals, which are often partially altered to serpentine or amphibole. Ilmenite is the dominant opaque mineral. The magnetite content is higher in the leucogabbro adjacent to the dolerite, possibly due to oxidation caused by the dolerite intrusion (Magnusson, 1983). Pyrrhotite is the most common sulphide. Small amounts of prismatic apatite are noted. Other, secondary minerals are cummingtonite-grunerite and chlorite.

\section{Sm-Nd isotope systematics}

Results from new $\mathrm{Sm}-\mathrm{Nd}$ isotopic analyses including four analyses of the rapakivi granite are reported in Table 1. One set of analyses was performed at the Mineralogical-Geological Museum, University of Oslo, Norway. This batch of samples was also analysed chemically as part of this investigation (cf. Fig. 2). The analytical procedures are described by Johansson \& Kullerud (1993), among others. An analysis of the international Johnson \& Matthew 321 Nd-standard during this period yielded ${ }^{143} \mathrm{Nd} /{ }^{144} \mathrm{Nd}=0.511117 \pm 12$ and ${ }^{145} \mathrm{Nd} /{ }^{144} \mathrm{Nd}=0.348425 \pm 5$. Errors are given as $2 \sigma$.

A second batch of analyses was performed at the Laboratory for Isotope Geology, Swedish Museum of Natural History, Stockholm. The analytical procedures followed that described by Claesson (1987), except that the ${ }^{143} \mathrm{Nd} /{ }^{144} \mathrm{Nd}$ ratios were determined on totally spiked samples (see also Andersson, 1997b). During the period when these rocks were analysed, 22 measured ${ }^{143} \mathrm{Nd} /{ }^{144} \mathrm{Nd}$ isotope ratios for the La Jolla $\mathrm{Nd}$ standard gave an average of $0.511754 \pm 16$, that is, 0.000100 less than the reference value $(0.511854)$. The sample analyses were corrected accordingly. Four measurements of the La Jolla $\mathrm{Nd}$ standard interspersed with the samples in this study gave a corrected mean ${ }^{143} \mathrm{Nd} /{ }^{144} \mathrm{Nd}$ ratio of $0.511860 \pm 8$. All data are normalized to ${ }^{146} \mathrm{Nd} /{ }^{144} \mathrm{Nd}=0.7219$. This second set was collected independently of sampling for whole-rock chemical analyses, and consequently there is no exact correspondence with the chemical data.

All $\varepsilon_{\mathrm{Nd}(1.58)}$ values are negative, varying between -1.1 and -3.3 for the gabbro, between -1.1 and -2.7 for the leucogabbro and between -2.7 and -3.1 for the new analyses of the granite. These granite data completely overlap with those reported by Lindh \& Johansson (1996). All $\varepsilon_{\mathrm{Nd}}$ data are displayed in Figure 3 together with data for some other Fennoscandian rapakivi complexes and early Svecofennian granitoids and metasediments. Table 1 displays depleted-mantle model ages for the Nordingrå complex. They vary between 2.13 and $2.42 \mathrm{Ga}$ for the gabbro, between 2.07 and $2.28 \mathrm{Ga}$ for the leucogabbro and between 2.25 and $2.34 \mathrm{Ga}$ for the granites. The depleted mantle is modelled according to DePaolo's (1981a) equation.

\section{Chemical composition of gabbro and leucogabbro}

The chemical data come from two data sets. Twentyone gabbro and seventeen leucogabbro analyses are from samples directly collected for this investigation

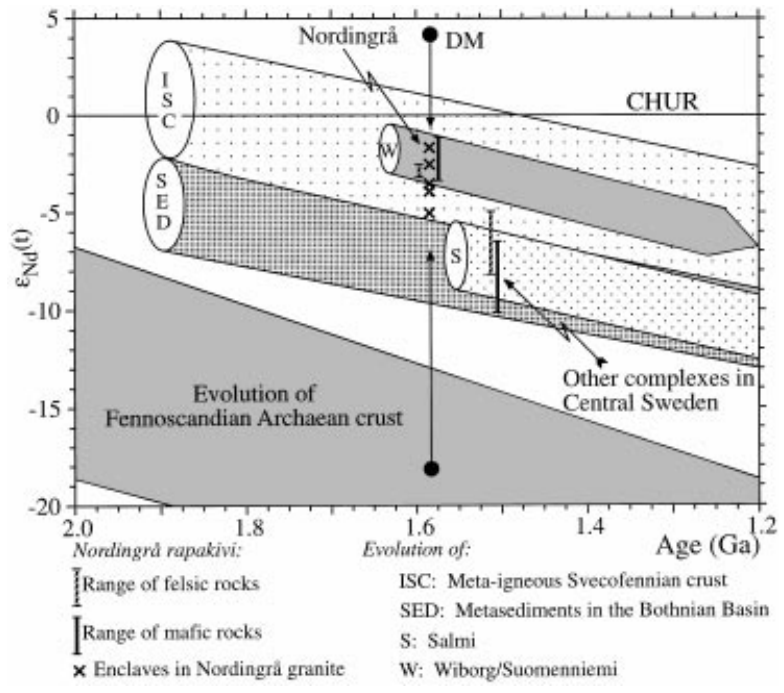

Figure 3. Time-evolution of the ${ }^{143} \mathrm{Nd} /{ }^{144} \mathrm{Nd}$ isotope ratio (whole rocks). Note that the $\varepsilon_{\mathrm{Nd}(1.58)}$ values of the basic rapakivi rocks are totally encompassed in the time-integrated development of the early Svecofennian granitoids. Also, note the small range of Nordingrå rapakivi granites and the much larger range of felsic enclaves in the granite, partly overlapping the younger westerly massifs. The composition of the Archaean crust used for modelling is indicated with a solid circle. DM = Depleted mantle. References for the different fields and data, in addition to those reported here, may be found in Andersson (1997b), Andersson, Neymark \& Billström (in press), Claesson (1987), Welin, Christiansson \& Kähr (1993) and Claesson \& Lundqvist (1995). 
Table 1. Results from the Sm-Nd isotope analyses

\begin{tabular}{|c|c|c|c|c|c|c|c|c|}
\hline Sample & Rock & $\begin{array}{l}\mathrm{Sm} \\
(\mathrm{ppm})\end{array}$ & $\begin{array}{c}\mathrm{Nd} \\
(\mathrm{ppm})\end{array}$ & $\frac{{ }^{147} \mathrm{Sm}}{{ }^{144} \mathrm{Nd}}$ & $\frac{{ }^{143} \mathrm{Nd}}{{ }^{144} \mathrm{Nd}} \pm 2 \sigma$ & $\begin{array}{c}\mathrm{T}_{\mathrm{DM}} \\
\varepsilon_{\mathrm{Nd}(1.58 \mathrm{Ga})}\end{array}$ & $(\mathrm{Ga})$ & $\begin{array}{c}\text { Sample locations } \\
\text { (Swedish National } \\
\text { Grid) }\end{array}$ \\
\hline $125^{* *}$ & Gabbro & 4.472 & 20.00 & 0.1352 & $0.511946 \pm 5$ & -1.1 & 2.13 & $698250 / 162225$ \\
\hline $311 * *$ & Gabbro & 12.149 & 53.81 & 0.1365 & $0.511456 \pm 7$ & -2.1 & 2.24 & $699290 / 162675$ \\
\hline $312 * *$ & Gabbro & 4.116 & 18.31 & 0.1359 & $0.511929 \pm 7$ & -1.6 & 2.18 & $698470 / 162695$ \\
\hline $031 *$ & Gabbro & 9.904 & 42.63 & 0.1405 & $0.511914 \pm 6$ & -2.8 & 2.36 & $698325 / 162470$ \\
\hline $032 *$ & Gabbro & 5.983 & 25.16 & 0.1438 & $0.511939 \pm 9$ & -3.0 & 2.42 & $698295 / 162490$ \\
\hline $033^{*}$ & Gabbro & 3.417 & 14.60 & 0.1415 & $0.511927 \pm 4$ & -2.7 & 2.36 & $698490 / 162700$ \\
\hline $034^{*}$ & Gabbro & 9.807 & 43.30 & 0.1369 & $0.511853 \pm 8$ & -3.3 & 2.37 & $698140 / 162670$ \\
\hline $036^{*}$ & Gabbro & 7.967 & 34.04 & 0.1415 & $0.511930 \pm 8$ & -2.7 & 2.36 & $698110 / 162280$ \\
\hline $038^{*}$ & Gabbro & 7.413 & 31.33 & 0.1430 & $0.511947 \pm 7$ & -2.6 & 2.37 & $697585 / 163400$ \\
\hline $119 * *$ & Leucogabbro & 2.662 & 11.92 & 0.1350 & $0.511927 \pm 11$ & -1.4 & 2.16 & $697690 / 163385$ \\
\hline $123 * *$ & Leucogabbro & 1.870 & 9.32 & 0.1213 & $0.511720 \pm 5$ & -2.7 & 2.18 & $697870 / 162855$ \\
\hline $320 * *$ & Leucogabbro & 0.969 & 4.69 & 0.1257 & $0.511848 \pm 9$ & -1.1 & 2.07 & $697750 / 162895$ \\
\hline $035^{*}$ & Leucogabbro & 3.290 & 13.82 & 0.1439 & $0.511999 \pm 8$ & -1.8 & 2.28 & $698145 / 162670$ \\
\hline $86037^{*}$ & Leucogabbro & 3.887 & 16.97 & 0.1384 & $0.511955 \pm 8$ & -1.6 & 2.20 & $697700 / 163370$ \\
\hline $040 *$ & Granite & 15.80 & 72.63 & 0.1315 & $0.511804 \pm 5$ & -3.1 & 2.30 & $698690 / 163200$ \\
\hline $041^{*}$ & Granite & 15.05 & 71.17 & 0.1278 & $0.511779 \pm 8$ & -2.8 & 2.25 & $698890 / 163410$ \\
\hline $042 *$ & Granite & 15.80 & 70.32 & 0.1359 & $0.511851 \pm 13$ & -3.1 & 2.34 & $699665 / 163285$ \\
\hline $037^{*}$ & Granite & 15.07 & 68.54 & 0.1333 & $0.511844 \pm 6$ & -2.7 & 2.28 & $701315 / 165100$ \\
\hline BCR-1 & Basalt std. & 6.561 & 28.87 & 0.1374 & $0.512629 \pm 9$ & & & \\
\hline
\end{tabular}

* Determined at the Laboratory for Isotope Geology, Museum of Natural History, Stockholm, Sweden.

** Determined at the Mineralogisk-Geologisk Museum, University of Oslo, Norway.

All $\varepsilon_{\mathrm{Nd}(\mathrm{T})}$ values refer the intrusion age of the Nordingrå granite, $1.58 \mathrm{Ga} \cdot{ }^{147} \mathrm{Sm} /{ }^{144} \mathrm{Nd}=0.1966$ and ${ }^{143} \mathrm{Nd} /{ }^{144} \mathrm{Nd}=0.512638$ are used for the present-day chondrite.

and have not been published earlier. The analytical results are reported in Tables 2 (major elements) and 3 (trace elements). These analyses were performed at the Geolaboratory of the Geological Department, Lund University, employing XRF, AAS, photospectrometry and INAA. The analytical procedures are described in more detail by Solyom, Lindqvist \& Johansson (1992). Additional data (113 gabbros and 81 leucogabbros) have been presented by G. Lundqvist (unpub. FLthesis, Univ. Gothenburg, 1976).

Selected Harker diagrams (Fig. 4) demonstrate the distinct chemical separation between gabbro and leucogabbro. However, scattering is considerable, especially for the leucogabbro. $\mathrm{SiO}_{2}$ contents are largely above $52 \%$, thus, many of the 'gabbros' are in fact intermediate rocks. The $\mathrm{K}_{2} \mathrm{O}$ content of the leucogabbro is lower than that of the gabbro within most of the variation field (Fig. 5) despite significant overlap. The gabbro has a high $\mathrm{K}_{2} \mathrm{O}$ content and especially a very high $\mathrm{K}_{2} \mathrm{O} / \mathrm{Na}_{2} \mathrm{O}$ ratio, which already at $\mathrm{SiO}_{2}=58 \%$ is typical of granites. A regression analysis indicates that about half of the $\mathrm{K}_{2} \mathrm{O} / \mathrm{Na}_{2} \mathrm{O}$ variation is tied to the $\mathrm{SiO}_{2}$ variation (coefficient of determination $=0.47$; $\mathrm{cf}$. Fig. 5). No covariance between $\mathrm{K}_{2} \mathrm{O} / \mathrm{Na}_{2} \mathrm{O}$ and the $\mathrm{Mg}$-number or any other single element can be found. The residuals seem to be equally distributed over the entire variation range.

All leucogabbros have $\mathrm{SiO}_{2}$ contents above 49\%. However, this does not imply that the leucogabbros are more differentiated than the gabbros. In Figure 6, the data are plotted against the $\mathrm{Mg}$-number (based on the molecular content of magnesium, ferrous and ferric iron) as the independent parameter. The spread in
Mg-number is essentially identical for leucogabbro and gabbro, indicating similar differentiation ranges for both. In addition, to display the conspicuous chemical separation of gabbro and leucogabbro, Figure 6 suggests Ti first to behave incompatibly but later to become compatible reaching its maximum at about the Mg-number 0.25. The rock sequence is iron-enriched; the maximum Mg-number (0.52) is almost identical to the mean $\mathrm{Mg}$-number of basalt (0.53) found by Le Maitre (1976), which is significantly different from primitive values.

Plagioclase, orthopyroxene and clinopyroxene dominate the normative mineralogy. Most samples lack normative olivine; others have minor amounts and only a few have major amounts. The preponderance of $\mathrm{Ca}$-poor pyroxene over Ca-rich pyroxene is very evident from the normative plag-opx-cpx diagram (Fig. 7). In terms of normative mineralogy, the rocks could be described as norite, gabbro-norite (of which only two samples are orthopyroxene gabbro), leuconorite and anorthosite. There is a small overlap between noritic and leuco-noritic rocks. The two outliers, a gabbro (GL46) and the orthopyroxene gabbro (318), do not have much in common. The leucogabbro has a low Mg-number (0.28), is low in Al and is fairly high in $\mathrm{Ca}$. The orthopyroxene gabbro has a high $\mathrm{Mg}$-number (0.51); it is also high in Ca and rather low in Al. High $\mathrm{Mg}$-numbers are found in a few leucogabbros, but only in those with low $\mathrm{Mg}$ - and $\mathrm{Fe}$-contents.

The ratios between incompatible trace elements show no consistent trends. The ratio $\mathrm{Ce} / \mathrm{La}$ is almost constant in the gabbro, mean $=1.9,1 \sigma=0.1$. This is a little less than the primordial mantle value, 2.6, suggested by 
Table 2. Results of major element analyses, set 1; for sample locations, see Figure 2

\begin{tabular}{|c|c|c|c|c|c|c|c|c|c|c|c|c|}
\hline Sample & $\mathrm{SiO}_{2}$ & $\mathrm{TiO}_{2}$ & $\mathrm{Al}_{2} \mathrm{O}_{3}$ & $\mathrm{Fe}_{2} \mathrm{O}_{3}$ & $\mathrm{FeO}$ & $\mathrm{MnO}$ & $\mathrm{MgO}$ & $\mathrm{CaO}$ & $\mathrm{Na}_{2} \mathrm{O}$ & $\mathrm{K}_{2} \mathrm{O}$ & $\mathrm{P}_{2} \mathrm{O}_{5}$ & LOI \\
\hline \multicolumn{13}{|c|}{ Leucogabbro and anorthosite } \\
\hline 119 & 50.9 & 0.90 & 23.6 & 0.7 & 5.4 & 0.09 & 1.35 & 10.4 & 3.8 & 0.91 & 0.25 & 1.8 \\
\hline 120 & 52.2 & 0.85 & 24.0 & 0.8 & 4.2 & 0.08 & 1.61 & 9.8 & 3.83 & 1.01 & 0.05 & 1.6 \\
\hline 121 & 51.9 & 0.61 & 24.2 & 0.7 & 4.6 & 0.08 & 1.71 & 10.4 & 3.79 & 0.80 & 0.11 & 1.0 \\
\hline 122 & 51.6 & 0.38 & 23.9 & 0.6 & 4.1 & 0.09 & 2.52 & 10.3 & 3.47 & 1.13 & 0.05 & 1.9 \\
\hline $123 \mathrm{~A}$ & 56.6 & 0.27 & 24.1 & 0.5 & 1.4 & 0.03 & 0.30 & 8.5 & 4.13 & 1.99 & 0.02 & 1.9 \\
\hline $123 \mathrm{~B}$ & 53.8 & 1.04 & 22.2 & 0.9 & 4.5 & 0.09 & 1.00 & 9.2 & 3.79 & 1.63 & 0.13 & 1.8 \\
\hline $123 \mathrm{~W}$ & 57.1 & 0.24 & 24.0 & 0.7 & 1.4 & 0.03 & 0.23 & 8.4 & 4.31 & 1.89 & 0.04 & 1.9 \\
\hline 124 & 52.8 & 1.15 & 22.9 & 1.1 & 4.2 & 0.08 & 1.03 & 9.5 & 3.76 & 1.12 & 0.23 & 1.4 \\
\hline $127 \mathrm{C}$ & 54.5 & 0.42 & 24.1 & 0.6 & 2.5 & 0.05 & 0.41 & 9.1 & 4.46 & 1.51 & 0.11 & 2.1 \\
\hline $127 \mathrm{D}$ & 55.5 & 0.42 & 23.8 & 0.7 & 3.2 & 0.06 & 0.40 & 9.1 & 4.19 & 1.34 & 0.09 & 1.3 \\
\hline 320 & 52.8 & 0.31 & 27.8 & 0.5 & 1.2 & 0.02 & 0.45 & 11.3 & 4.35 & 0.60 & 0.05 & 0.7 \\
\hline 504 & 53.1 & 1.15 & 22.7 & 0.9 & 5.3 & 0.09 & 1.12 & 9.9 & 3.67 & 1.01 & 0.26 & 1.3 \\
\hline 505 & 52.2 & 0.40 & 26.6 & 0.4 & 1.7 & 0.04 & 0.49 & 11.0 & 3.86 & 1.58 & 0.06 & 1.9 \\
\hline 506 & 52.4 & 0.11 & 28.6 & 0.3 & 0.8 & 0.02 & 0.52 & 12.4 & 3.76 & 0.59 & 0.02 & 0.6 \\
\hline 507 & 52.3 & 1.54 & 21.9 & 1.3 & 6.0 & 0.13 & 1.36 & 9.4 & 3.63 & 0.90 & 0.26 & 1.7 \\
\hline 508 & 53.5 & 0.99 & 22.4 & 1.2 & 5.2 & 0.09 & 0.94 & 9.9 & 3.59 & 1.12 & 0.27 & 1.2 \\
\hline 511 & 52.7 & 0.26 & 26.3 & 0.6 & 2.1 & 0.04 & 1.21 & 9.8 & 4.31 & 1.14 & 0.04 & 2.0 \\
\hline \multicolumn{13}{|l|}{ Gabbro } \\
\hline 125 & 49.3 & 1.71 & 16.4 & 1.2 & 12.7 & 0.18 & 5.52 & 7.5 & 2.64 & 1.26 & 0.25 & 1.3 \\
\hline 126 & 49.4 & 2.32 & 14.8 & 1.3 & 14.1 & 0.21 & 4.78 & 7.2 & 2.65 & 1.40 & 0.33 & 1.0 \\
\hline 127 & 50.8 & 1.54 & 16.6 & 2.4 & 12.7 & 0.23 & 1.52 & 6.2 & 3.47 & 1.40 & 0.45 & 2.4 \\
\hline 135 & 49.6 & 3.60 & 14.6 & 1.0 & 13.1 & 0.22 & 4.38 & 7.8 & 2.62 & 1.29 & 0.29 & 1.0 \\
\hline 140 & 50.3 & 1.75 & 15.9 & 1.1 & 12.7 & 0.19 & 4.96 & 6.9 & 2.78 & 1.50 & 0.26 & 1.3 \\
\hline 141 & 50.6 & 2.60 & 14.2 & 1.1 & 13.9 & 0.21 & 3.89 & 6.9 & 2.72 & 1.86 & 0.42 & 1.1 \\
\hline $127 \mathrm{~B}$ & 47.0 & 1.89 & 17.6 & 2.1 & 15.1 & 0.27 & 1.74 & 7.0 & 3.52 & 0.67 & 0.42 & 2.4 \\
\hline 311 & 49.9 & 3.64 & 13.3 & 1.5 & 14.1 & 0.22 & 3.36 & 6.7 & 2.62 & 2.40 & 0.90 & 1.4 \\
\hline 312 & 47.8 & 1.60 & 16.5 & 1.5 & 12.4 & 0.18 & 6.90 & 7.6 & 2.73 & 1.07 & 0.32 & 1.3 \\
\hline 313 & 48.4 & 1.20 & 17.3 & 0.8 & 12.7 & 0.18 & 6.50 & 7.9 & 2.78 & 0.95 & 0.24 & 1.0 \\
\hline 315 & 50.3 & 2.41 & 14.3 & 1.4 & 13.5 & 0.22 & 4.63 & 7.0 & 2.69 & 1.65 & 0.43 & 1.6 \\
\hline 318 & 48.4 & 1.39 & 14.4 & 0.2 & 13.0 & 0.24 & 7.49 & 9.6 & 2.84 & 0.32 & 0.12 & 2.0 \\
\hline 408 & 47.1 & 3.31 & 13.3 & 1.8 & 16.9 & 0.26 & 3.12 & 7.9 & 2.75 & 1.21 & 1.00 & 1.0 \\
\hline 501 & 54.3 & 2.30 & 14.1 & 1.2 & 12.3 & 0.20 & 2.11 & 6.2 & 2.88 & 2.41 & 0.71 & 1.1 \\
\hline 502 & 46.4 & 1.52 & 17.6 & 2.4 & 10.3 & 0.16 & 6.06 & 7.8 & 2.39 & 0.85 & 0.13 & 4.7 \\
\hline 503 & 51.5 & 2.53 & 14.0 & 1.0 & 14.4 & 0.22 & 2.73 & 7.2 & 2.95 & 1.77 & 0.63 & 1.2 \\
\hline 509 & 51.8 & 2.90 & 13.3 & 1.3 & 14.6 & 0.22 & 3.33 & 6.7 & 2.59 & 2.08 & 0.50 & 1.1 \\
\hline 510 & 51.6 & 3.93 & 13.2 & 1.3 & 14.1 & 0.22 & 3.19 & 6.5 & 2.63 & 2.06 & 0.42 & 1.2 \\
\hline 512 & 59.7 & 1.60 & 13.6 & 1.5 & 10.1 & 0.16 & 1.86 & 4.7 & 2.87 & 2.44 & 0.49 & 1.5 \\
\hline 516 & 51.4 & 2.77 & 13.6 & 1.0 & 14.7 & 0.33 & 3.58 & 6.8 & 2.85 & 1.87 & 0.48 & 1.0 \\
\hline 518 & 51.9 & 2.73 & 13.6 & 0.9 & 14.4 & 0.21 & 3.50 & 6.7 & 2.59 & 1.93 & 0.47 & 1.3 \\
\hline
\end{tabular}

LOI - Loss on ignition

Wood (1979), and the chondrite value, 2.64, reported by Nakamura (1974). Other pairs vary more, e.g. La/Lu with a factor of approximately 15 between minimum (4) and maximum (64) values (cf. the REE-diagram, Fig. 10). The ratio between the two 'continental' elements $\mathrm{Ba}$ and $\mathrm{Rb}$ shows a large variation.

The $\mathrm{Cr} / \mathrm{Ni}$ ratio in the gabbro varies strongly, between 0.4 and 42 , but few values are above $15 . \mathrm{Cr} / \mathrm{Ni}$ ratios show a poorly defined peak between $\mathrm{Mg}$-numbers 0.3 and 0.4 (Fig. 8). Contamination from continental crust does not affect the $\mathrm{Cr} / \mathrm{Ni}$ ratio, so this variation must have originated early in the development, possibly due to fractionation. To the best of our knowledge, chromite has never been reported from the Nordingrå gabbro. In spite of this, it cannot be ruled out that sporadic high Cr-concentration is due to the accidental presence of chromite in a few samples. We do not believe that a systematic removal or accumulation of chromite has influenced the $\mathrm{Cr} / \mathrm{Ni}$ ratio.

Figure 9 shows concentrations of various elements normalized to the primordial mantle (Wood, 1979). The fractionation between large-ion lithophile elements (LILE) and high field strength elements (HFSE) is limited in the gabbros and only slightly more pronounced in the leucogabbros. Conspicuous is a negative Sr-anomaly in most of the gabbros and a complementary positive anomaly in most of the leucogabbros. The $(\mathrm{Rb} / \mathrm{Ba})_{\mathrm{N}}$ ratios (subscribed $\mathrm{N}$ stands for a normalized ratio) are scattered in both gabbro and leucogabbro (gabbro mean 1.0; $\sigma=0.4$; one extreme value, 24 from sample 318 , is omitted, leucogabbro mean 1.1 and $\sigma=0.6)$. Likewise, $(\mathrm{K} / \mathrm{Rb})_{\mathrm{N}}$ ratios scatter. No significant correlation between the $\mathrm{Mg}$-number and the $\mathrm{K} / \mathrm{Rb}$ ratio is found.

The primary mantle-normalized concentrations of $\mathrm{Ta}$ and $\mathrm{Nb}$ are lower than their neighbouring elements in Figure 9. This applies to the gabbro as well as the leucogabbro. However, the primordial mantlenormalized $\mathrm{Nb} / \mathrm{Ta}$ ratios are close to but mostly slightly below 1 . 


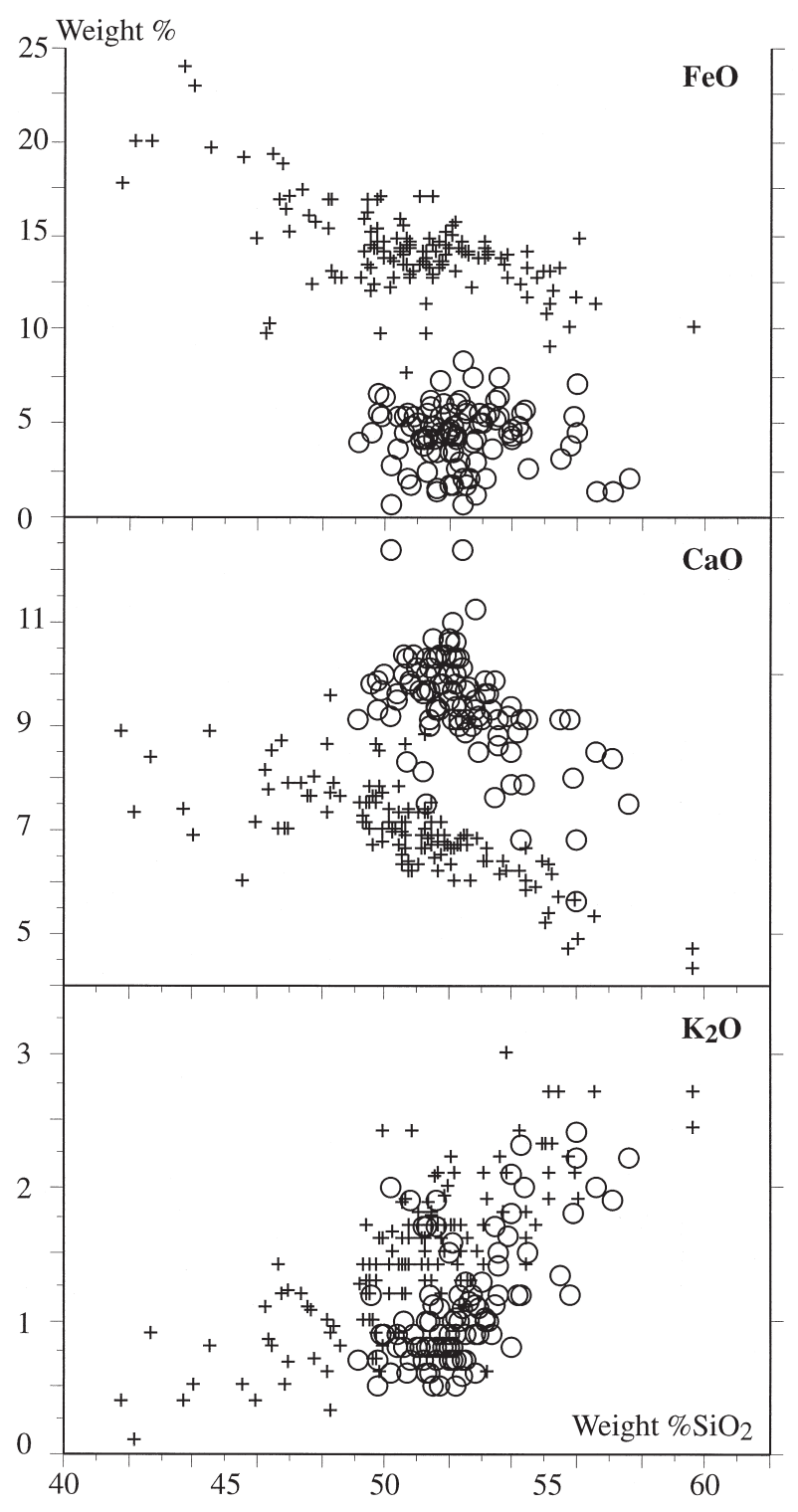

Figure 4. Selected Harker diagrams for gabbros (crosses) and leucogabbros (open rings).

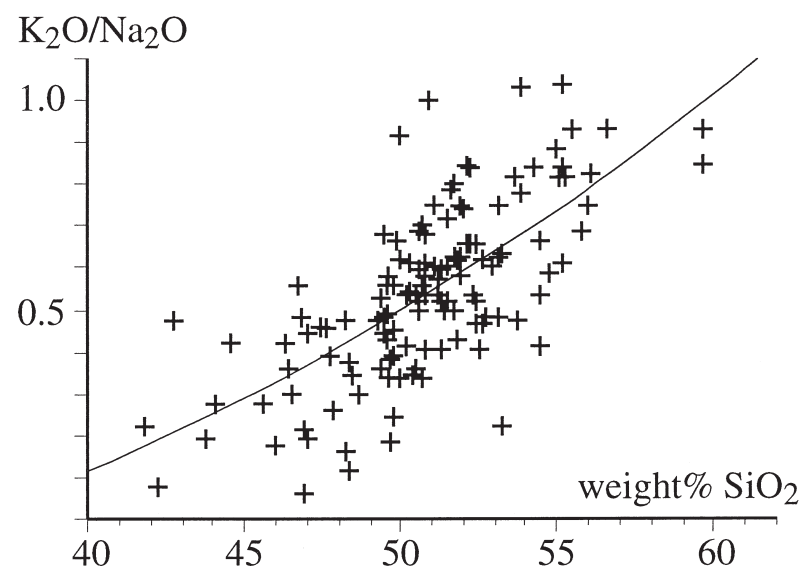

Figure 5. Plot of the ratio $\mathrm{K}_{2} \mathrm{O} / \mathrm{Na}_{2} \mathrm{O}$ against $\mathrm{SiO}_{2}$ for the Nordingrå complex gabbro.

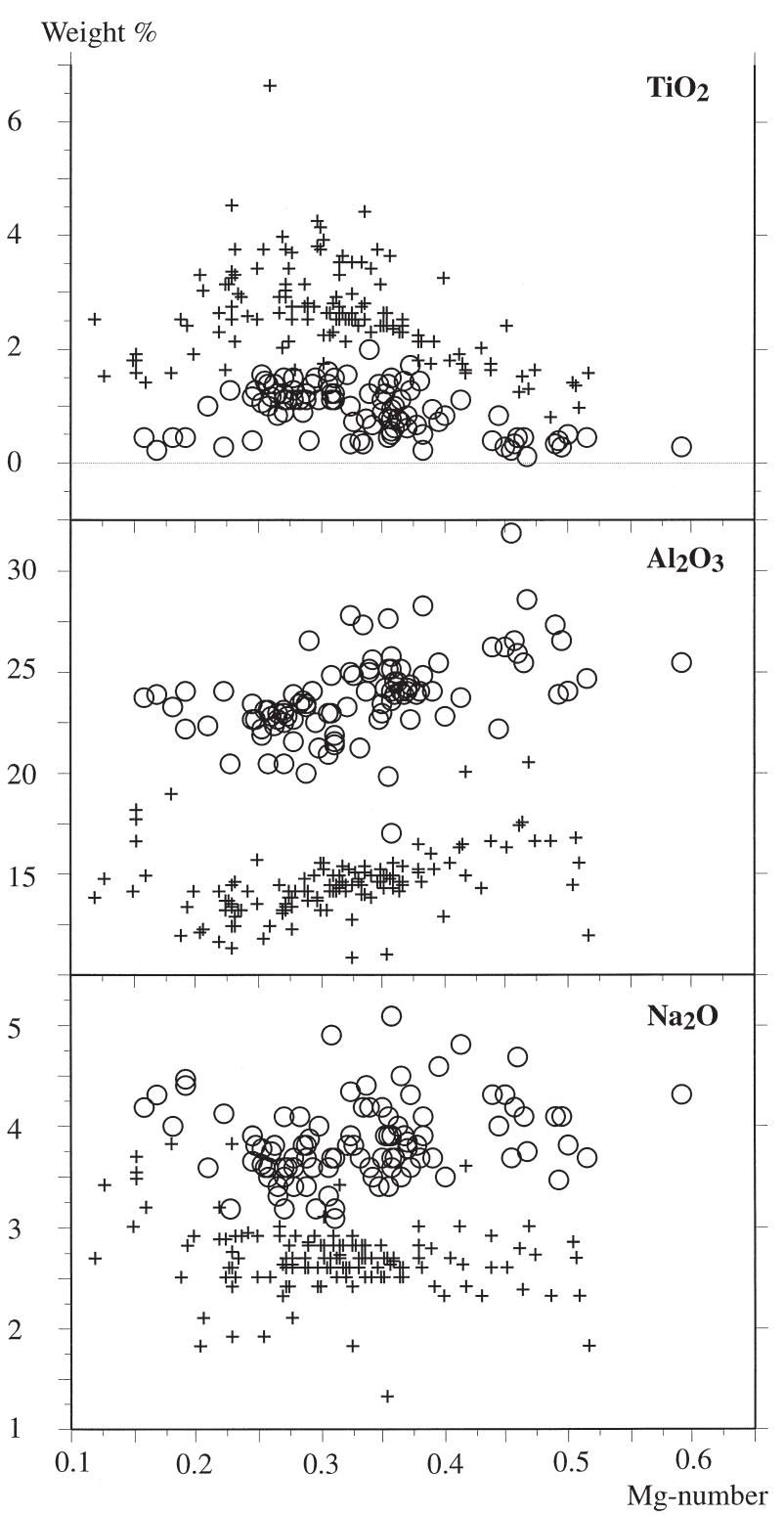

Figure 6. Major elements plotted vs. the Mg-number. The elements plotted are selected to show the differences between gabbro (crosses) and leucogabbro (open rings) in the Nordingrå complex.

Figure 10 shows chondrite-normalized REE analyses. A weak negative slope is typical, with chondritenormalized $\mathrm{La} / \mathrm{Lu}$ ratios varying between 3.8 and 6.6 for the gabbros. The leucogabbros with one exception show a similar slope (3.7 to 7.9 ).

The gabbros have small negative Eu anomalies. The minimum $\mathrm{Eu} / \mathrm{Eu}^{*}$ ratio is 0.74 . Three rocks classified as gabbro have positive Eu-anomalies. Their major element chemistry is intermediate between gabbro and leucogabbro. All leucogabbros except the anomalous rock mentioned above have a pronounced positive Eu-anomaly. The small positive Ho-anomaly might be an artefact of the chondrite analysis used for normalizing. 
Table 3. Results of trace element determinations, set 1; for sample locations, see Figure 2

\begin{tabular}{|c|c|c|c|c|c|c|c|c|c|c|c|c|c|c|c|c|c|c|c|c|c|c|}
\hline Sample & $\mathrm{Ba}$ & $\mathrm{Cr}$ & $\mathrm{Nb}$ & $\mathrm{Rb}$ & $\mathrm{Sc}$ & $\mathrm{Sr}$ & $\mathrm{Y}$ & $\mathrm{Zr}$ & $\mathrm{La}$ & $\mathrm{Ce}$ & $\mathrm{Nd}$ & $\mathrm{Sm}$ & $\mathrm{Eu}$ & $\mathrm{Tb}$ & $\mathrm{Yb}$ & $\mathrm{Lu}$ & $\mathrm{Ta}$ & Hf & $\mathrm{Ga}$ & Cs & Th & $\mathrm{U}$ \\
\hline \multicolumn{23}{|c|}{ Leucogabbro/anorthosite } \\
\hline 119 & 214 & 13 & 6 & 27 & 14 & 380 & 16 & 46 & 10.5 & 21 & 14 & 2.8 & 1.74 & 0.53 & 1.26 & 0.21 & 0.36 & 1.4 & 23 & 0.9 & 1.7 & 1.0 \\
\hline 120 & 230 & & 5 & 36 & & 378 & 12 & 57 & & & & & & & & & & & 24 & & & \\
\hline 121 & 223 & 12 & $*$ & 19 & 9.5 & 383 & 13 & 41 & 10.2 & 18 & 11 & 2.3 & 1.62 & 0.42 & 1.08 & 0.22 & 0.27 & 1.5 & 22 & 0.8 & 1.6 & 0.8 \\
\hline 122 & 182 & 37 & $*$ & 42 & 10.5 & 366 & 9 & 24 & 5 & 10 & 8 & 1.1 & 1.39 & 0.2 & 0.65 & 0.14 & 0.22 & 0.9 & 21 & 0.7 & 1.1 & 0.9 \\
\hline $123 \mathrm{~A}$ & 483 & 7 & 5 & 65 & 6.3 & 362 & 10 & 77 & 10.8 & 21 & 11 & 2.1 & 2.13 & 0.3 & 0.98 & 0.18 & 0.36 & 2.2 & 26 & 4.5 & 5.5 & 1.3 \\
\hline 124 & 311 & & 8 & 34 & & 370 & 21 & 74 & & & & & & & & & & & 25 & & & \\
\hline $123 \mathrm{~B}$ & 361 & & 7 & 61 & & 353 & 27 & 91 & & & & & & & & & & & 25 & & & \\
\hline $127 \mathrm{C}$ & 431 & & 7 & 43 & & 477 & 13 & 52 & & & & & & & & & & & 27 & & & \\
\hline $127 \mathrm{D}$ & 439 & & 7 & 45 & & 410 & 18 & 97 & & & & & & & & & & & 26 & & & \\
\hline 320 & 193 & & & 18 & & 513 & & 31 & & & & & & & & & & & 19 & & & \\
\hline 504 & 345 & & 9 & 24 & & 396 & 24 & 95 & & & & & & & & & & & & & & \\
\hline 505 & 216 & 16 & $*$ & 50 & 4.6 & 454 & 7 & 45 & 6.4 & 11 & 9 & 1.3 & 1.54 & 0.22 & 0.61 & $*$ & $*$ & 1.1 & & 1.6 & 1.1 & 1.0 \\
\hline 506 & 192 & 20 & $*$ & $*$ & 1.6 & 586 & $*$ & 18 & 2.7 & 4 & * & 0.3 & 1.09 & $*$ & $*$ & $*$ & $*$ & 1.1 & & 0.8 & $*$ & 1.0 \\
\hline 507 & 327 & 26 & 14 & 22 & 21 & 377 & 26 & 94 & 17 & 36 & 21 & 5.0 & 1.99 & 1.01 & 2.49 & 0.42 & 1.05 & 2.6 & & 1.6 & 2.7 & 1.3 \\
\hline 508 & 346 & & 7 & 33 & & 374 & 23 & 82 & & & & & & & & & & & & & & \\
\hline 511 & 425 & & $*$ & 26 & & 536 & 5 & 26 & & & & & & & & & & & & & & \\
\hline $123 \mathrm{~W}$ & 483 & 15 & $*$ & 53 & 6.7 & 375 & 14 & 108 & 15 & 28 & 15 & 2.9 & 2.19 & 0.48 & 1.31 & 0.26 & 0.41 & 3.2 & & 4.6 & 4.9 & 0.8 \\
\hline \multicolumn{23}{|l|}{ Gabbro } \\
\hline 125 & 348 & 27 & 10 & 48 & 24 & 277 & 30 & 120 & 19 & 35 & 23 & 4.8 & 1.57 & 0.85 & 2.66 & 0.43 & 0.52 & 3.5 & 20 & 2.7 & 4.1 & 2.2 \\
\hline 126 & 423 & 34 & 9 & 41 & 32 & 237 & 37 & 148 & 23 & 44 & 30 & 6.3 & 1.72 & 1.06 & 3.46 & 0.57 & 0.71 & 4.1 & 18 & 1.4 & 4.4 & 1.4 \\
\hline 127 & 686 & 26 & 25 & 45 & 35 & 389 & 46 & 91 & 41 & 79 & 49 & 11 & 3.95 & 1.52 & 3.92 & 0.64 & 1.36 & 2.3 & 29 & 1.7 & 4.1 & 2.2 \\
\hline 135 & 360 & & 12 & 45 & & 234 & 30 & 127 & & & & & & & & & & & 20 & & & \\
\hline 140 & 428 & & 8 & 59 & & 250 & 28 & 126 & & & & & & & & & & & 19 & & & \\
\hline 141 & 536 & 32 & 10 & 60 & 35 & 211 & 49 & 208 & 31 & 60 & 35 & 8.3 & 1.93 & 1.44 & 4.39 & 0.7 & 0.84 & 5.5 & 20 & 1.5 & 6.0 & 2.5 \\
\hline $127 \mathrm{~B}$ & 423 & & 16 & 14 & & 426 & 23 & 34 & & & & & & & & & & & 32 & & & \\
\hline 311 & 662 & & 19 & 103 & & 190 & 66 & 309 & & & & & & & & & & & 25 & & & \\
\hline 312 & 297 & & 7 & 39 & & 288 & 25 & 117 & & & & & & & & & & & 18 & & & \\
\hline 313 & 273 & & 7 & 30 & & 291 & 22 & 94 & & & & & & & & & & & 18 & & & \\
\hline 315 & 476 & & 12 & 56 & & 234 & 44 & 184 & & & & & & & & & & & 22 & & & \\
\hline 318 & 27 & & 6 & 59 & & 133 & 16 & 90 & & & & & & & & & & & 16 & & & \\
\hline 408 & 466 & & 21 & 45 & & 251 & 60 & 152 & & & & & & & & & & & 20 & & & \\
\hline 405 & 674 & & 19 & 129 & & 166 & 53 & 218 & & & & & & & & & & & 21 & & & \\
\hline 501 & 609 & & 23 & 106 & & 224 & 56 & 192 & & & & & & & & & & & & & & \\
\hline 502 & 200 & 80 & 7 & 24 & 13.5 & 314 & 15 & 87 & 12 & 24 & 12 & 2.5 & 1.34 & 0.55 & 1.27 & 0.23 & 0.56 & 2.5 & & 0.6 & 2.1 & 1.6 \\
\hline 503 & 726 & & 17 & 63 & & 225 & 59 & 129 & & & & & & & & & & & & & & \\
\hline 509 & 625 & 40 & 13 & 63 & 38 & 187 & 63 & 224 & 34 & 70 & 38 & 8.7 & 2.05 & 1.56 & 4.78 & 0.75 & 0.95 & 6.8 & & 1.4 & 5.1 & 2.8 \\
\hline 510 & 533 & & 14 & 61 & & 196 & 42 & 234 & & & & & & & & & & & & & & \\
\hline 516 & 608 & & 12 & 46 & & 200 & 44 & 206 & & & & & & & & & & & & & & \\
\hline 518 & 606 & & 11 & 47 & & 201 & 53 & 193 & & & & & & & & & & & & & & \\
\hline 512 & 719 & 36 & 18 & 86 & 31 & 245 & 55 & 250 & 44 & 95 & 51 & 10.5 & 2.25 & 1.78 & 4.96 & 0.77 & 1.37 & 7.6 & & 3.3 & 9.0 & 3.7 \\
\hline
\end{tabular}

* Below detection limit

\section{Interpretations and discussion}

Previously described field data suggest a co-magmatic relation among gabbro, leucogabbro and anorthosite and that rocks occur as multiple intrusive bodies. The chemical trends shown in Figures 4 and 6 suggest that plagioclase separation occurred at all stages of the evolution, as was also demonstrated by G. Lundqvist (unpub. FL-thesis, Univ. Gothenburg, 1976). These two figures also show the clear distinction between gabbro and leucogabbro and, specifically in Figure 6, that all rocks are iron-enriched.

Figures 3 to 8 display the chemical and isotopic evolution of the mafic Nordingrå magmas. The possible major causes for this evolution are various degrees of partial melting, crystal differentiation and assimilation of crustal rocks. All three processes drive the evolution in a similar direction, which makes it difficult to estimate the contribution from each one separately.

The strong iron-enrichment causes an increased magma density, which helps plagioclase to float and separate. Approximate magma densities for the gabbros are estimated for a magma temperature of $1200{ }^{\circ} \mathrm{C}$ using the method designed by Bottinga \& Weill (1970) and modified by McBirney (1993). The results vary between $2.7 \times 10^{3}$ and $3.1 \times 10^{3} \mathrm{~kg} / \mathrm{m}^{3}$ with a mean of $2.8 \times 10^{3} \mathrm{~kg} / \mathrm{m}^{3}$. All plagioclases are negatively buoyant in magmas of a composition corresponding to this mean value, whereas a magma of a composition corresponding to the minimum value only allows plagioclase more albite-rich than approximately $\mathrm{An}_{55} \mathrm{Ab}_{45}$ to float. This means that in the Nordingrå gabbro, plagioclase will float in all but the most Mg-rich magmas. However, the degree of separation depends on kinetic factors governed by viscosity, size of crystals and density contrast.

The Mg-number monitors the chemical evolution. The $\mathrm{K} / \mathrm{Rb}$ ratio and the Ni-content show only weak correlations and the $\mathrm{Ba} / \mathrm{Rb}$ ratio and $\mathrm{Cr}$-content no correlations to the $\mathrm{Mg}$-number; this does not suggest 


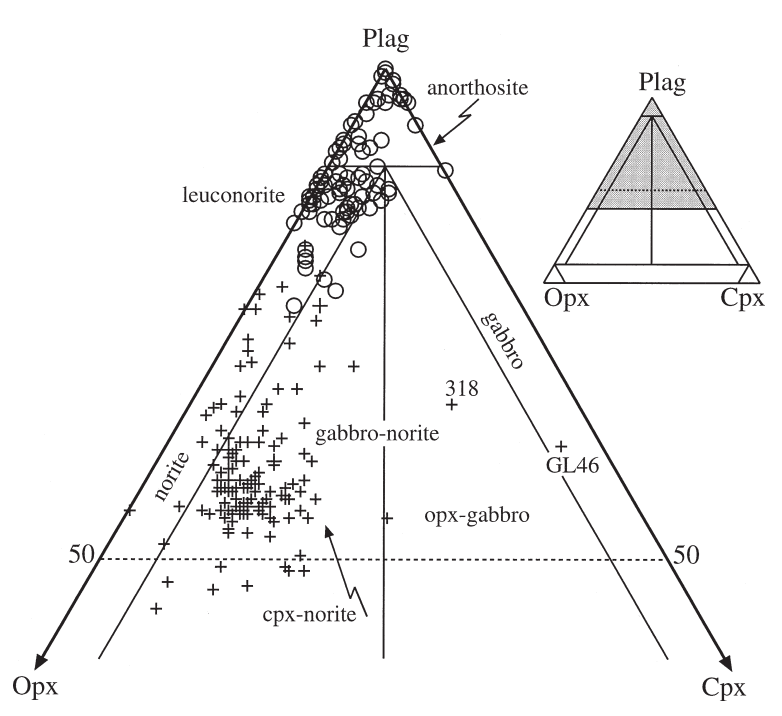

Figure 7. Normative plagioclase, orthopyroxene and clinopyroxene for gabbro (crosses) and leucogabbro/ anorthosite (open rings). Fields after Streckeisen (1976).

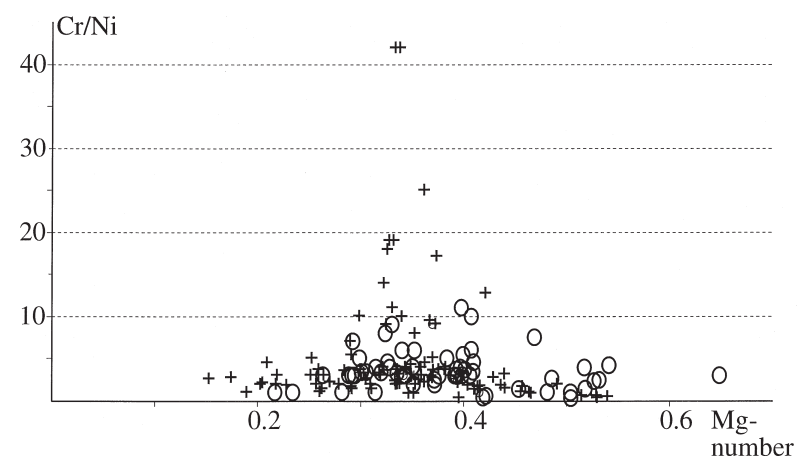

Figure 8. The ratio $\mathrm{Cr} / \mathrm{Ni}$ plotted against the $\mathrm{Mg}$-number for gabbros (crosses) and leucogabbros (open rings).

crystal differentiation as the only mechanism for the evolution. At approximate equilibrium conditions, melts from a reasonably homogeneous mantle do not produce mantle-normalized $\mathrm{K} / \mathrm{Rb}$ ratios both larger and smaller than one, even after crystal fractionation. These ratios should be close to but somewhat smaller than one in the primary melt.

\section{6.a. Constraints from the isotopic composition}

Two major models could explain low initial $\varepsilon_{\mathrm{Nd}}$ values of the basic Nordingrå rocks: either an enriched mantle source or contamination by low- $\varepsilon_{\mathrm{Nd}}$ crustal rocks. Neither from early Svecofennian (Huhma, 1986; Patchett, Todt \& Gorbatschev, 1987; Björklund \& Claesson, 1992; P. J. Valbracht, unpub. Ph.D. thesis, Amsterdam, 1991) nor from 'Postjotnian times' (Claesson, 1987; Rämö, 1990; Patchett et al. 1994; Andersson, 1997b,c) have enriched mantle-derived
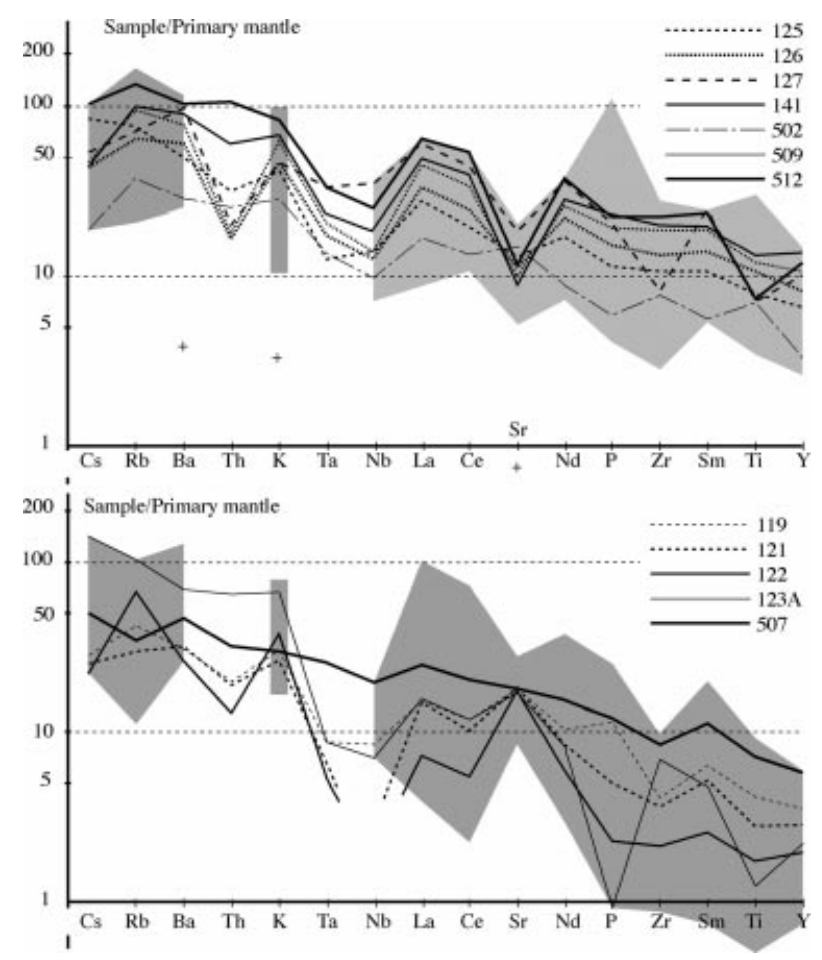

Figure 9. Primary mantle-normalized trace element patterns. The upper diagram shows results from the gabbros and the lower from the leucogabbros in the Nordingra complex. Shown in grey is the range of data for incomplete analyses. The three crosses show data out of normal range for Ba (sample 318), K (GL3) and Sr (GL136). These samples are indicative of assimilation of depleted crust.

rocks been demonstrated in the Svecofennian Orogen. Mafic rocks from these periods generally indicate a mildly to strongly depleted source. The presence of an enriched subcontinental mantle-source specifically at $1.58 \mathrm{Ga}$ appears unlikely. Claesson \& Lundqvist (1995) considered a mantle of about two-thirds the depletion of the depleted mantle of DePaolo (1981a) to be appropriate for this region. Moreover, the geochemical character and variation (see Sections 6.b and 6.c), for example, the opx-normative, noritic composition, are more consistent with crustal contamination as the cause for the negative $\varepsilon_{\mathrm{Nd}}$ values.

The obtained data thus suggest at least two major reservoirs, one in the mantle and one in the continental crust. Andersson (1997c), Andersson, Neymark \& Billström (in press) and Persson (1997) showed that Archaean lower crustal reservoirs are required for the Subjotnian magmatism of rapakivi complexes with even lower initial $\varepsilon_{\mathrm{Nd}}(-10$ to -5$)$ elsewhere in Central Sweden. The time-integrated evolution of the early Svecofennian meta-igneous rocks (Fig. 3) encompasses the Nordingrå rocks, suggesting that the rapakivi granites may be derived from such sources (Lindh \& Johansson, 1996). The mean $\varepsilon_{\mathrm{Nd}(1.58)}$ of early Svecofennian granitoids in the Bothnian Basin area is -3.9 (mean $\mathrm{Nd}$ content $=c$. $35 \mathrm{ppm}$, cf. compilation in Andersson, Neymark \& 

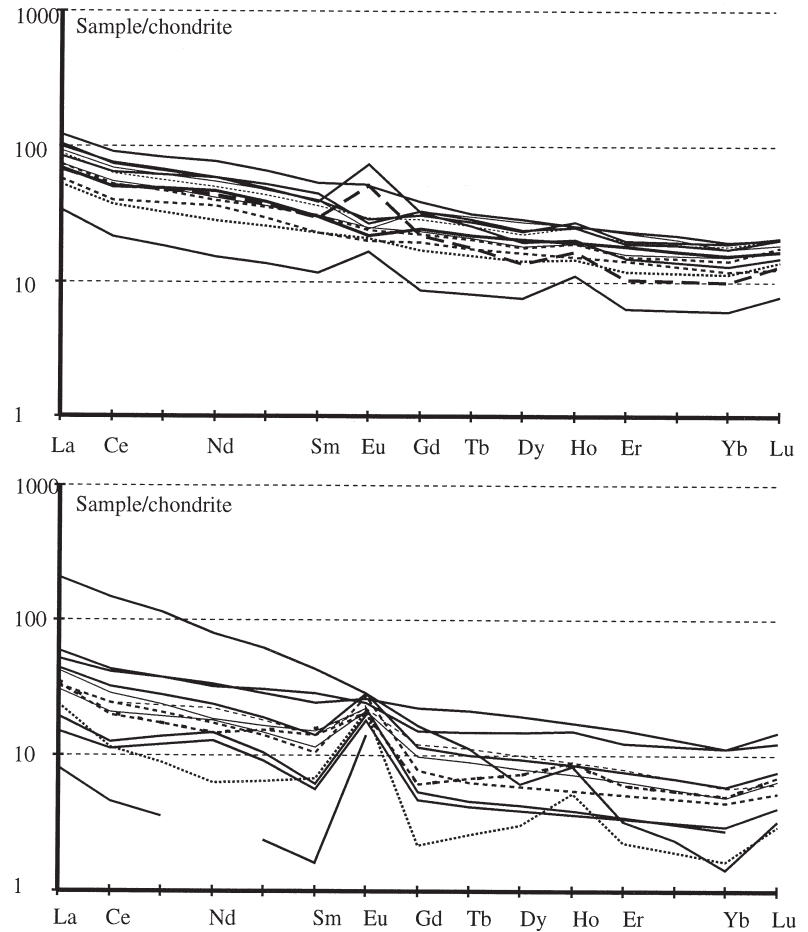

Figure 10. Chondrite-normalized REE diagrams. The upper diagram shows results from the gabbros and the lower from the leucogabbros. Interrupted lines are due to contents below the detection limit. Lines are differently ornamented to allow tracing of slopes.

Billström, in press), that is, not much different from that of the most negative Nordingrå gabbro (-3.3). Mixing calculations using this mean and a mildly depleted mantle magma (Claesson \& Lundqvist, 1995) with $\varepsilon_{\mathrm{Nd}(1.58)}=$ +2.9 and $5-15 \mathrm{ppm} \mathrm{Nd}$, yields reasonably low $(<c$. $25 \%$ ) values of bulk assimilation only for the least negative gabbros and less than $10 \mathrm{ppm} \mathrm{Nd}$ in the primary mantle magma. Only when assuming that the contaminant to a primary mantle magma with only $5 \mathrm{ppm} \mathrm{Nd}$ has an $\varepsilon_{\mathrm{Nd}(1.58)}$ less than -6 , the proportion of crustal rocks becomes $<25 \%$ for the more negative gabbros. Since early Svecofennian meta-igneous reservoirs are not, in general, expected to show such negative $\varepsilon_{\mathrm{Nd}(1.58)}$ values, partly Archaean contaminants are likely. Using an average Archaean component compiled from literature data (Martin et al. 1983; Jahn, Vidal \& Kröner, 1984; Huhma, 1986; Öhlander et al. 1987; Mellqvist, 1996, 1999, in press) on Archaean rocks in the northeastern part of the Shield, with an average Nd content of 25-30 ppm and $\varepsilon_{\mathrm{Nd}(1.58)}=-17.4$, yields reasonable crustal contributions to all the mafic Nordingrå magmas varying between 5 and 20\%. Mixed Archaean-early Svecofennian contributions are accordingly also plausible, where, at least for the most negative rocks, Archaean components should dominate.

The high $\mathrm{Nd}$ content of several gabbros requires either:

(1) that the Archaean and/or Svecofennian conta-

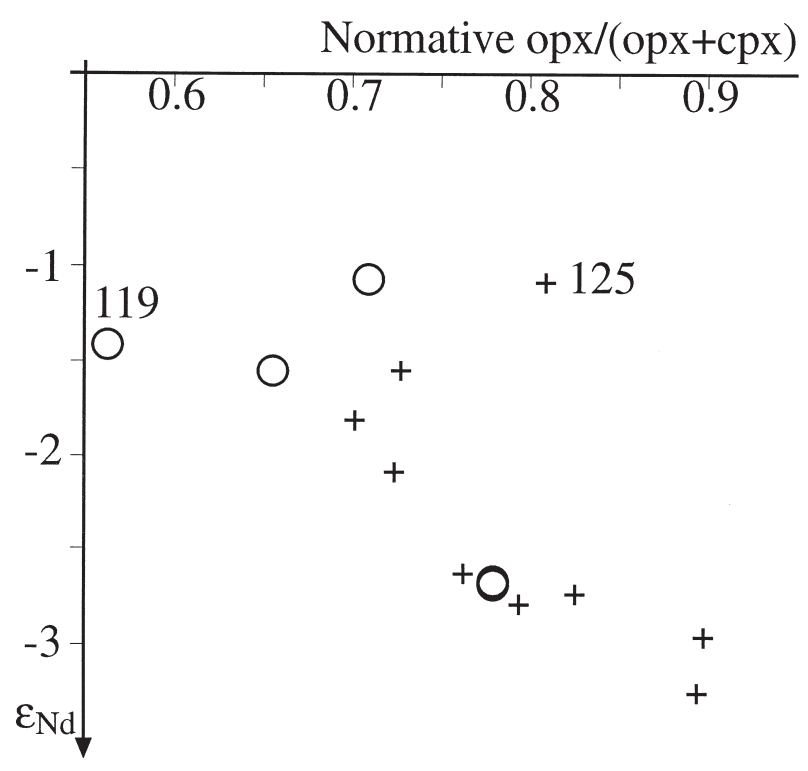

Figure 11. The ratio normative opx/(opx $+\mathrm{cpx})$ plotted against $\varepsilon_{\mathrm{Nd}}$ for nine gabbros (crosses) and five leucogabbros (open rings) in the Nordingrå complex.

minant were partly much higher in Nd than the average, which is possible as both groups range up to at least $70 \mathrm{ppm}$, or

(2) that the coeval rapakivi magma (c. $70 \mathrm{ppm} \mathrm{Nd;}$ Table 1) was in part an additional component, or

(3) that crystal fractionation raised the LREE content.

All three processes are likely to have contributed; their relative importance is impossible to determine. In contrast, the low Nd content of a few gabbros may implicate participation of the low-Nd depleted crustal residue (pyroxene+plagioclase dominated) left after rapakivi melt extraction (cf. Emslie \& Hegner, 1993; Emslie, Hamilton \& Thériault, 1994).

Additional support for an Archaean influence in the Nordingrå Complex comes from Nd-isotope data obtained from quartz-syenite enclaves in the Nordingrå granite (T. Mårtensson, unpub. Masters thesis, Univ. Lund, 1997). These enclaves represent an early felsic magmatic phase, which yields scattered but partly lower $\varepsilon_{\mathrm{Nd}(1.58)}$ than in the host granite.

\section{6.b. Constraints from the major element compositions}

Major element data are ambiguous when trying to discriminate among crystal differentiation, varying degrees of partial melting or contamination as cause for chemical diversification. However, no mantle gives a primary liquid as iron- and silica-rich as found among the Nordingrå gabbros. Thus, we exclude variable degrees of partial melting as the prime cause for chemical variation.

The Nordingra gabbro is not a gabbro in the strict sense. Besides partly being too siliceous to be termed a basic rock, it is more precisely described as a K-rich, 


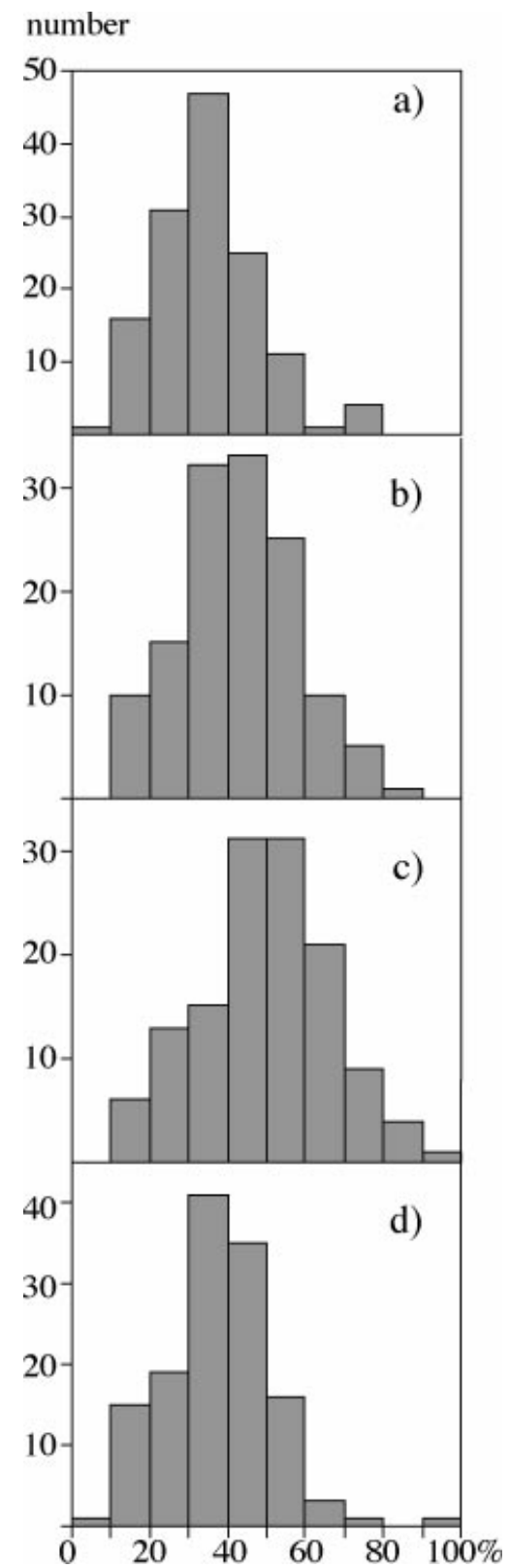

Figure 12. Results from tests of crustal bulk-rock assimilation. The horizontal scale gives percentage of assimilation and the vertical scale numbers of rocks in each class. Assimilated rocks: (a) local early Svecofennian granitoids with $\mathrm{SiO}_{2}>65 \%$; (b) 'all' local early Svecofennian granitoids; (c) average tonalite according to Le Maitre (1976); (d) local metagreywackes.

olivine-clinopyroxene norite (cf. Fig. 7). Already Bowen (1928) suggested that norites resulted from contamination of mafic magmas with continental crust. More recently the norite problem has been discussed by Macera et al. (1994), among others, who consider mixing of crustally derived acid magmas and mantle derived basic magmas to explain the formation of the Cima D'Asta norite. Chai \& Eckstrand (1994) suggested that strong contamination (up to $60 \%$ ) with Archaean lower crustal material was instrumental in the formation of the Sudbury norite.

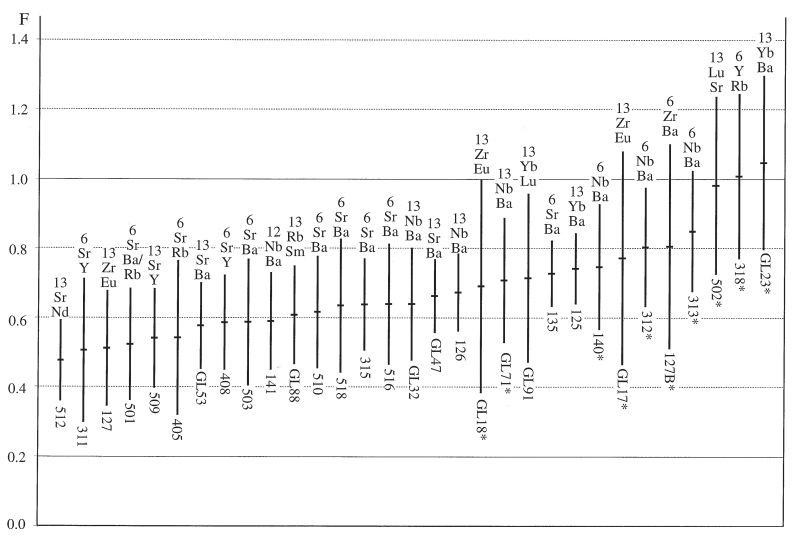

Figure 13. Results of the AFC test for trace elements. Bars give the obtained $F$-value $\pm 1 \sigma$. ( $F=$ fraction of remaining magma). The sample number is given below each bar. An asterisk indicates that at least one $F>1$. Above the bar are indicated the number of elements included in the mean for each sample, the element giving the highest and the element giving the lowest $F$-value. $\mathrm{Ba}, \mathrm{Rb}, \mathrm{Sr}, \mathrm{Nb}, \mathrm{Y}$ and $\mathrm{Zr}$ are included in the means for six elements. In addition to these elements, $\mathrm{Ce}, \mathrm{Nd}, \mathrm{Sm}, \mathrm{Eu}, \mathrm{Tb}, \mathrm{Yb}$ and $\mathrm{Lu}$ are included in the means for thirteen elements.

In order to form norite, crustal rocks provide the components alumina and silica from reacting phases to the magma leading to reactions of the types:

$$
\begin{aligned}
& {\left[\mathrm{Ca}(\mathrm{Mg}, \mathrm{Fe}) \mathrm{Si}_{2} \mathrm{O}_{6}\right]_{\text {мЕІт }}+\mathrm{Al}_{2} \mathrm{O}_{3}+\mathrm{SiO}_{2} \rightarrow \mathrm{CaAl}_{2} \mathrm{Si}_{2} \mathrm{O}_{8}+} \\
& (\mathrm{Mg}, \mathrm{Fe}) \mathrm{SiO}_{3} \text { and } \\
& {\left[(\mathrm{Mg}, \mathrm{Fe})_{2} \mathrm{SiO}_{4}\right]_{\text {MEIT }}+\mathrm{SiO}_{2} \rightarrow 2(\mathrm{Mg}, \mathrm{Fe}) \mathrm{SiO}_{3 .}}
\end{aligned}
$$

$\left[\mathrm{Ca}(\mathrm{Mg}, \mathrm{Fe}) \mathrm{Si}_{2} \mathrm{O}_{6}\right]_{\mathrm{MELT}}$ and $\left[(\mathrm{Mg}, \mathrm{Fe})_{2} \mathrm{SiO}_{4}\right]_{\mathrm{MELT}}$ correspond to components in the primary magma. Corona formations on olivine suggest that already crystallized olivine also takes part in the reaction. These or similar reactions explain not only the noritic character of the rock but also an increased content of plagioclase leading to the formation of leucogabbro and anorthosite. Emslie \& Hegner (1993), Emslie, Hamilton \& Thériault (1994) and Dempster, Preston $\&$ Bell (1999) among others have suggested continental crust as a contaminant in anorthosite genesis. Dempster, Preston \& Bell (1999) concluded that 'underplating basalts and juvenile undifferentiated lower crustal rocks are the key to the anorthosite problem'. In some investigations (e.g. Emslie \& Hegner, 1993), authors have stressed that the contaminant should have a restitic character. We also note that strongly plagioclase-depleted rocks like ferrodiorites, which often accompany anorthosite massifs (see, e.g. Bhattacharya et al. 1998; Mark1, Frost \& Bucher, 1998), representing the liquid after removal of fractionating plagioclase, have not been identified in the Nordingrå massif. The lack of restitic liquid after plagioclase removal is, together with constraints from the isotope analyses, consistent with the suggestion 


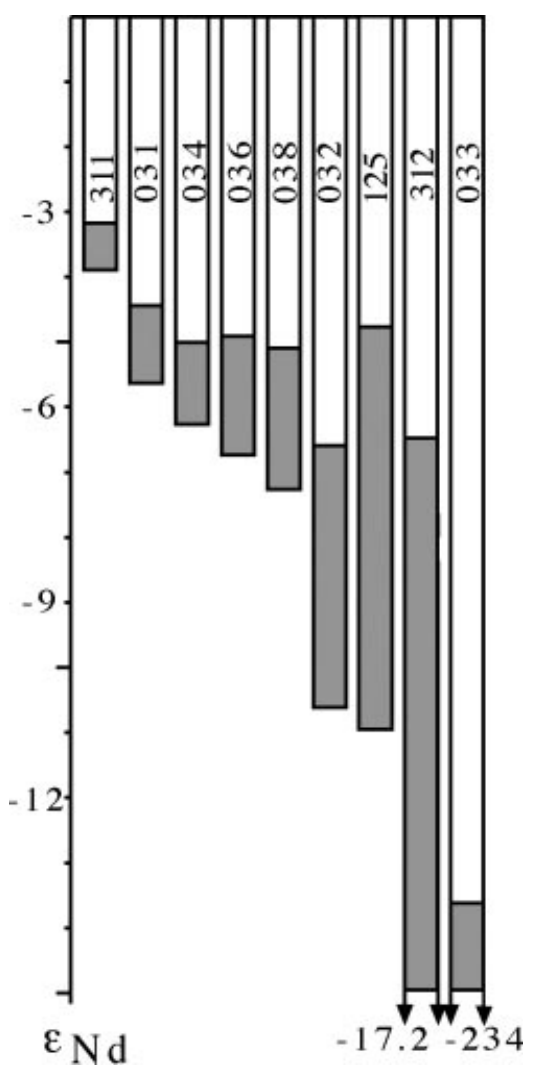

Figure 14. Results of the AFC test for Nd isotopes. $\varepsilon_{\mathrm{Nd}(1.58)}$ refers to the value of the assimilated rock; the corresponding value for the primary magma is assumed to be 2.9. Unfilled columns correspond to the least negative and filled columns to the most negative $\varepsilon_{\mathrm{Nd}(1.58)}$.

that continental crust contributes much of the material necessary for anorthosite formation.

If the noritic character of these rocks is due to crustal contamination of a 'normal mantle melt', we should find a negative correlation between this character and the $\varepsilon_{\mathrm{Nd}(1.58)}$. However, crustal rocks are always heterogeneous and various amounts of crystal differentiation give a variable parent magma. Thus we cannot expect a straight-line behaviour between two defined endmembers but scattering between two components, which both show some chemical variability. The second set of chemical analyses was not performed on the same rock powder used for $\mathrm{Sm}-\mathrm{Nd}$ analyses, which introduces additional scatter. Nevertheless, the correlation between $\varepsilon_{\mathrm{Nd}(1.58)}$ and the ratio normative opx/(opx + cpx $)$ is high (-0.7; Fig. 11).

A test as to whether merely bulk assimilation of crustal rocks explains the noritic character of the gabbro involves successive subtraction of the tested assimilated rock from the gabbro analysis until no normative orthopyroxene remains. We tested one greywacke and three igneous compositions as contaminants. Figure 12 displays the results, suggesting high degrees of bulk contamination. The model also suggests a mantle-derived magma of an 'impossible' composition. Alternatively, the assimilated rocks would be rich in Fe-extreme mafic minerals, rich in $\mathrm{SiO}_{2}$ and simultaneously very poor in alkalis. These considerations lead to a suggestion involving not only bulk assimilation but also selective contributions from the crust. Extensive, initial crystal fractionation explains much of the Fe-enrichment. The dominating fractionating phases must be olivine, which is effective in reducing the $\mathrm{Mg}$-number, and to a lesser and variable extent clinopyroxene, to explain the lack of a correlation between $\mathrm{Ni}$ and $\mathrm{Mg}$ and between $\mathrm{Ni}$ and $\mathrm{Cr}$. The noritic character of the final rock excludes large amounts of late orthopyroxene fractionation after crustal assimilation.

\section{6.c. Constraints from the trace element composition}

In the Nordingrå gabbro, incompatible trace-element ratios, e.g. $\mathrm{K} / \mathrm{Rb}, \mathrm{Rb} / \mathrm{Ba}, \mathrm{Nb} / \mathrm{Ta}$ and $\mathrm{Rb} / \mathrm{Nb}$, vary considerably. This strongly suggests more than one source for the magmas. One of these sources must be in the mantle and the other(s) in the continental crust. This is consistent with conclusions from $\mathrm{Sm}-\mathrm{Nd}$ isotopes and major element analyses.

Extensive crystal differentiation explains the Fe-enrichment and assimilation the noritic character of the rock. Varying $\mathrm{Ni} / \mathrm{Cr}$ ratios point to various degrees of olivine separation before crustal assimilation processes. The low normalized $\mathrm{Nb}$ and $\mathrm{Ta}$ contents (Fig. 9) are consistent with suggestion of assimilation of crustal material. Intraplate mafic magmatic rocks are not supposed to be depleted in these two elements compared to the neighbouring elements in Figure 9. Bulk assimilation may be part of the process but is incapable of reproducing the entire range of rock compositions. The scattered $\mathrm{Rb} / \mathrm{Ba}$ ratios point to inhomogeneous source regions, in this case a reasonably constant mafic source and varying degrees of assimilation of a non-homogeneous continental component. Assimilation-FractionationCrystallization (AFC) processes contribute to explaining both the Fe-rich and the noritic character. Testing follows the procedure suggested by DePaolo (1981b), applying the simplifying border conditions of a constant assimilation to fractionation ratio ( $r$ in DePaolo's equation) and a constant total distribution coefficient (weighted average, $D$ in DePaolo's equation) between magma and the crystallizing phases. We use a small value of $r(0.4)$, since much heat is lost due to the simultaneous formation of the rapakivi granite magma. This test is, however, rather insensitive to the exact value of $r$. We assume the fractionating phases plagioclase $(60 \%)>$ olivine $(30 \%)>>$ clinopyroxene (10\%, cf. Irvine, 1976). A high content of plagioclase among the fractionating phases explains the formation of leucogabbro and anorthosite and a high content of olivine the Fe-enrichment and the increased orthopyroxene content in the rock. The degree of clinopyroxene fractionation is probably variable. We use the 


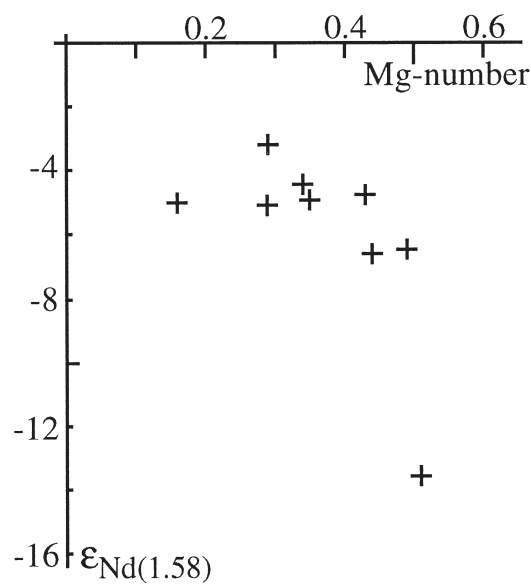

Figure 15. $\varepsilon_{\mathrm{Nd}(1.58)}$ of assimilated rock satisfying DePaolo's (1981b) equation as a function of the Mg-number. Boundary conditions as described in the text.

composition of average silicic $\left(>65 \% \mathrm{SiO}_{2}\right)$ early Svecofennian granitoids (as in the major element test) and two primary mantle magma compositions.

Using an enriched magma corresponding to an Ocean Island Basalt (see compilation by Sun \& McDonough, 1989) results in failed tests for almost all elements. The outcome of the test is appraised from the similarity of the fractions of remaining liquid ( $F$ in DePaolo's equation) for all tested elements. Thus, isotope and trace element evidence confirms that the primary magma was not enriched.

Testing a more depleted primary magma corresponding to an E-MORB (see compilation by Sun \& McDonough, 1989) meets with more success (cf. results in Fig. 13). Normally, $F$ is less than one, even if there are exceptions. Analytical errors alone do not explain all of the scattering, indicating that the model does not account for all of the variation. Strontium is strongly overrepresented among the elements with high $F$-values and Ba among those with low $F$-values (Fig. 13). The most probable explanations for high $F$ values for $\mathrm{Sr}$ is an overestimate of the $\mathrm{Sr}$-content in the model's original magma. The low $F$-values for Ba may be due either to underestimates of $\mathrm{Ba}$ in the original magma or overestimates in the contaminant. Further, the absorbed continental crust was not homogeneous and different batches of the mafic melt had probably experienced different degrees of fractional crystallization before the onset of the AFC process. A combination of bulk assimilation, AFC and early crystal fractionation might explain most of the variation of the rock suite.

An additional AFC test uses the $\mathrm{Nd}$ isotopes (DePaolo, 1981b). Border conditions are: the same $D$ values used in the first AFC-test, $\varepsilon_{\mathrm{Nd} 1.58}$ of the subcontinental mantle $=2.9$ (estimated from the suggestion of Claesson \& Lundqvist, 1995), primary Nd content equal to $9 \mathrm{ppm}$ (E-MORB suggested by Sun \& McDonough, 1989), $r$ varying between 0.3 and 0.9 and
$F$ between 0.6 and 0.8 . The results of the calculation are estimates of the $\varepsilon_{\mathrm{Nd}(1.58)}$ of the assimilated crust (assuming $30 \mathrm{ppm} \mathrm{Nd}$ ). Figure 14 displays the results. The least negative $\varepsilon_{\mathrm{Nd}}$ (unfilled columns) is obtained for the largest $r$ and the smallest $F$. Samples 033 and 312 require an unreasonably low $\varepsilon_{\mathrm{Nd}(1.58)}$ of the assimilated crust to satisfy the model. The low Nd contents of these two samples (cf. Table 1) make the modelling extremely sensitive to small errors in the Nd-content of the chosen original magma. The results for the other seven samples are accepted as a positive outcome of the test, where differences in obtained $\varepsilon_{\mathrm{Nd}}$ values can be explained with non-constant $D$-values (that is, they must vary during the process) and $F$-values that differ among the samples. There is a tendency among the data that samples with high Mg-numbers require a more negative $\varepsilon_{\mathrm{Nd}(1.58)}$ to satisfy the model (cf. Fig. 15). This is a hint that the primary magma might be less depleted than tentatively suggested by Claesson \& Lundqvist (1995). The results from the two samples 033 and 312 suggest the presence of a low-Nd contaminant, e.g. the depleted restite from the rapakivi magma extraction.

In addition to the types of contamination that have been tested, the coexisting rapakivi granite magma may contribute to the chemical composition of the mafic rocks (cf. Emslie, Hamilton \& Thériault, 1994; Andersson, 1997b). Lindh \& Johansson (1996) noted that the rapakivi granite is low in alumina leading to the formation of clinopyroxene and hornblende instead of biotite as mafic phases. They suggested the possibility that excess aluminium from crustal melting forming the rapakivi granite magma could enter into the coexisting mafic magma, thereby contributing to the increased Al-content manifest in an increased plagioclase production. The complete model for the mafic Nordingrå rocks must consider the assimilated rocks as well as the two magmas: the mantle-derived gabbroic magma and the crustal-derived granitic magma. It is also not fully understood how the physical intrusion of the separate mafic and felsic magmas occurred. Contrary to many other rapakivi complexes, the mafic rocks are concentrated at one end and the felsic rocks at the other end of the Nordingrå complex. The amount of mafic rocks underlying the northern part of the Nordingrå rapakivi granites and the extent of the Nordingra rapakivi complex eastwards under the sea are incompletely known.

\section{Conclusions}

(1) Varying degrees of partial melting of the mantle do not explain the observed chemical variation of the Nordingrå mafic magma; even the most $\mathrm{Mg}$-rich rock can hardly be a primary mantle melt. The noritic character of the rocks and the $\mathrm{Nd}$ isotope composition suggest other processes to be of prime importance for the formation of the rock sequence.

(2) Major and trace element chemistry suggests that only part of the observed chemical evolution can 
be explained by crystal differentiation from a reasonably homogeneous mantle melt, for example, some trace-element ratios are inconsistent with such a suggestion.

(3) The overlap of Mg-numbers from leucogabbros and gabbros suggests that plagioclase separation has occurred at all stages in the evolution of the Nordingrå gabbro norite.

(4) The Nd-isotope composition of the gabbroic rocks of the Nordingrå rapakivi complex requires, and its trace- and major-element chemistry strongly suggests, that crustal rocks were incorporated into the magma. In the absence of any strong evidence for an enriched sublithospheric mantle, the negative $\varepsilon_{\mathrm{Nd}(1.58)}$ values suggest an Archaean crustal component. Combined trace element and isotope studies suggest that AFC processes are of prime importance for explaining the chemical composition of the gabbros and leucogabbros. The associated granites can be explained by partial melting of early Svecofennian granitoids even if an involvement of older rocks is not excluded.

(5) The exact nature of the contaminants is difficult to quantify. Most probably contaminants are heterogeneous, including undepleted crust (e.g. represented by Archaean and the early Svecofennian granitoids), depleted crust (restitic after rapakivi magma extraction), and to some degree the rapakivi magma itself. A significant part of this crust should be Archaean in age.

Acknowledgements. Anders Lindh acknowledges financial support from the Swedish Counsel for Natural Science. The chemical analyses in set 1 were performed by Ingrid Johansson, at the Geolaboratory, Lund University. Hans Schöberg, Marina Fischerström and Ann-Marie Kähr at the Laboratory for Isotope Geology are thanked for technical assistance with isotope analyses. Lina Pudas and Rikard Anehus at the Geological Department, Lund University made the thin sections. Comments from T. Dempster and an anonymous referee have improved the manuscript.

\section{References}

Andersson, U. B. 1997a. An overview of the Fennoscandian rapakivi complexes with emphasis on the Swedish occurrences. In Rapakivi granites and related rocks in central Sweden (eds M. Ahl, U. B. Andersson, T. Lundqvist and K. Sundblad), pp. 33-49. Sveriges Geologiska Undersökning Ca87, Uppsala.

Andersson, U. B. 1997b. Petrogenesis of some Proterozoic granitoid suites and associated basic rocks in Sweden (geochemistry and isotope geology). Sveriges Geologiska Undersökning, Rapporter och meddelanden 91, Sveriges Geologiska Undersökning, 216 pp.

ANDERSSON, U. B. 1997c. The Subjotnian Strömsbro granite complex at Gävle, Sweden. GFF 119, 159-67.

Andersson, U. B., Neymark, L. A. \& Billström, K. in press. Petrogenesis of Mesoproterozoic (Subjotnian) rapakivi complexes of central Sweden: implications from $\mathrm{U}-\mathrm{Pb}$ zircon ages, $\mathrm{Nd}, \mathrm{Sr}$, and $\mathrm{Pb}$ isotopes. Transactions of the Royal Society of Edinburgh, Earth Sciences.

Bhattacharya, A., Raith, M., Hoernes, S. \& BanerJee,
D. 1998. Geochemical evolution of the massif-type anorthosite complex at Bolangir in the Eastern Ghats Belt of India. Journal of Petrology 39, 1169-96.

BJörklund, L. \& ClaEsson, S. 1992. Geochemical character and preliminary $\mathrm{Sm}-\mathrm{Nd}$ data on basic metavolcanic rocks in the Tiveden area, south Sweden. Geologiska Föreningens i Stockholm Förhandlingar 114, 340-1.

Bottinga, Y. \& Weill, D. F. 1970. Densities of liquid silicate systems calculated from residual molar volumes of oxide components. American Journal of Science $\mathbf{2 6 9}$, $169-82$.

BowEN, N. L. 1928. The evolution of the igneous rocks. Princeton: Princeton University Press, 334 pp.

Chai, G. \& Eckstrand, R. 1994. Rare earth element characteristics and origin of the Sudbury Igneous Complex, Ontario, Canada. Chemical Geology 113, 221-44.

Claesson, S. 1987. Nd isotope data on 1.9-1.2 Ga basic rocks and metasediments from the Bothnian Basin, central Sweden. Precambrian Research 35, 115-26.

Claesson, S., Huhma, H., Kinny, P. D. \& Williams, I. 1993. Svecofennian detrital zircon ages - implications for the Precambrian evolution of the Baltic Shield. Precambrian Research 64, 109-30.

Claesson, S. \& Lundquist, T. 1995. Origins and ages of Proterozoic granitoids in the Bothnian Basin, central Sweden: isotopic and geochemical constraints. Lithos 36, $115-40$.

Dempster, T. J., Preston, R. J. \& Bell, B. R. 1999. The origin of Proterozoic massif-type anorthosites: evidence from interactions between crustal xenoliths and basaltic magma. Journal of the Geological Society, London 156, 41-6.

DePaolo, D. J. 1981a. Neodymium isotopes in the Colorado Front Range and crust-mantle evolution in the Proterozoic. Nature 291, 193-6.

DePaolo, D. J. 1981b. Trace element and isotopic effects of combined wallrock assimilation and fractional crystallization. Earth and Planetary Science Letters 53, 189-202.

Emslie, R. F., Hamilton, M. A. \& Thériault, R. J. 1994. Petrogenesis of a Mid-Proterozoic AnorthositeMangerite-Charnockite-Granite (AMCG) Complex: Isotopic and chemical evidence from the Nain Plutonic Suite. Journal of Geology 102, 539-58.

Emslie, R. F. \& Hegner, E. 1993. Reconnaissance isotopic geochemistry of anorthosite-mangerite-charnockitegranite (AMCG) complexes, Grenville province, Canada. Chemical Geology 106, 279-98.

HiETANEN, A. 1975. Generation of potassium-poor magmas in the northern Sierra Nevada and the Svecofennian of Finland. U.S. Geological Survey, Journal of Research 3, 631-45.

Huhma, H. 1986. Sm-Nd, U-Pb and $\mathrm{Pb}-\mathrm{Pb}$ isotopic evidence for the origin of the Early Proterozoic Svecokarelian crust in Finland. Geological Survey of Finland, Bulletin 337, 1-52.

Högвom, A. G. 1909. The igneous rocks of Ragunda, Alnö, Rödö and Nordingrå. Geologiska Föreningens $i$ Stockholm Förhandlingar 31, 347-75.

Irvine, T. N. 1976. Metastable liquid immiscibility and $\mathrm{MgO}-\mathrm{FeO}-\mathrm{SiO}_{2}$ fractionation patterns in the system $\mathrm{Mg}_{2} \mathrm{SiO}_{4}-\mathrm{Fe}_{2} \mathrm{SiO}_{4}-\mathrm{CaAl}_{2} \mathrm{Si}_{2} \mathrm{O}_{8}-\mathrm{KAlSi}_{3} \mathrm{O}_{8}-\mathrm{SiO}_{2}$. Carnegie Institute Yearbook 75, 597-611.

JAHN, B.-M., VIDAL, P. \& KRÖNER, A. 1984. Multi-chronometric ages and origin of Archaean tonalitic gneisses in 
Finnish Lapland: a case for long crustal residence time. Contributions to Mineralogy and Petrology 86, 398-408.

JohANSSON, L. \& KUlLERUd, L. 1993. Late Sveconorwegian metamorphism and deformation in southwestern Sweden. Precambrian Research 64, 295-309.

Le Maitre, R. W. 1976. The chemical variability of some common igneous rocks. Journal of Petrology 17, 589-637.

Lindh, A. \& Johansson, I. 1996. Rapakivi granites of the Baltic Shield: The Nordingrå granite, its chemical variation and $\mathrm{Sm}-\mathrm{Nd}$ isotope variation. Neues Jahrbuch für Mineralogie, Abhandlungen 170, 291-312.

LundBohm, H. 1899. Praktiskt geologiska undersökningar inom Vesternorrlands län. II Berggrunden. Med två kartor $i$ skalorna 1:500000 resp. 1:1000000. Sveriges Geologiska Undersökning C177. Stockholm.

Lundqvist, T., Gee, D. G., Kumpulainen, R. \& Karis, L. 1990. Beskrivning till berggrundskartan över Västernorrlands län. Sveriges Geologiska Undersökning Ba31. Uppsala, 429 pp.

Lundevist, T., VaAsjoki, M. \& Persson, P. O. 1998. U-Pb ages of plutonic and volcanic rocks of the Svecofennian Bothnian Basin, Central Sweden, and their implications for the Palaeoproterozoic evolution of the Basin. GFF 120, 357-63.

Macera, P., Del Moro, A., Bagossi, G. M., Campana, R. \& Rottura, A. 1994. Polygenetic nature of the Cina d'Asta intrusive complex, southern Alps, Italy. Inferences from petrological, geochemical and isotopic (Sr and $\mathrm{Nd}$ ) data. Lithos 32, 47-65.

Magnusson, K.-Å. 1983. A petrophysical and paleomagnetic study of the Nordingra region in eastern Sweden. Sveriges Geologiska Undersökning C801, 70 pp.

Markl, G., Frost, B. R. \& Bucher, K. 1998. The origin of anorthosites and related rocks from the Lofoten Islands, Northern Norway: I. Field relations and estimation of intrinsic variables. Journal of Petrology 39, $1425-52$.

Martin, H., Chauvel, C., Jahn, B.-M. \& Vidal, P. 1983. $\mathrm{Rb}-\mathrm{Sr}$ and $\mathrm{Sm}-\mathrm{Nd}$ ages and isotope geochemistry of Archaean granodiorite gneisses from eastern Finland. Precambrian Research 35, 257-76.

McBirney, A. R. 1993. Igneous Petrology. Boston, London: Jones and Bartlett Publishers, 508 pp.

Mellqvist, C. 1996. Using Sm-Nd isotopes and the occurrence of Archaean megaxenoliths as tracers when delineating the Archaean-Proterozoic palaeoboundary in the Luleå area. GFF 118, A20.

Mellqvist, C., Öhlander, B., Skiöld, T. \& Wikström, A 1999. The Archaean-Proterozoic Palaeoboundary in the Luleå area, northern Sweden: field and isotope geochemical evidence for a sharp terrane boundary. Precambrian Research 96, 225-43.

Mellqvist, C., Öhlander, B. \& Skiöld, T. in press. Traces of Archaean crust in the Jokkmokk area, northern Sweden: a way of defining the Archaean-Proterozoic boundary. Precambrian Research.

Nakamura, N. 1974. Determination of REE, Ba, Fe, Mg, $\mathrm{Na}$, and $\mathrm{K}$ in carbonaceous and ordinary chondrites. Geochimica et Cosmochimica Acta 38, 757-75.

ÖHLANDER, B. \& Romer, R. 1996. Zircon ages of granites occurring along the Central Swedish Gravity Low. GFF 118, 217-25.

Öhlander, B., Skiöld, T., Hamilton, P. J. \& Claesson, L.A. 1987. The western border of the Archaean province of the Baltic Shield: evidence from northern Sweden. Contributions to Mineralogy and Petrology 95, 437-50.

Patchett, J., Todt, W. \& Gorbatschev, R. 1987. Origin of continental crust of $1.9-1.7 \mathrm{Ga}$ age; $\mathrm{Nd}$ isotopes in the Svecofennian orogen terrains of Sweden. Precambrian Research 35, 145-60.

Patchett, P. J., Lehnert, K., Rehkämper, M. \& Sieber, G. 1994. Mantle and crustal effects on the geochemistry of Proterozoic dikes and sills in Sweden. Journal of Petrology 35, 1095-1125.

Persson, A. 1997. The Ragunda rapakivi complex. In Rapakivi granites and related rocks in central Sweden (eds M. Ahl, U. B. Andersson, T. Lundqvist and K. Sundblad), pp. 49-58. Sveriges Geologiska Undersökning Ca87, Uppsala.

Romer, R. L. \& SMeds, S.-A. 1994. Implications of U-Pb ages of columbite-tantalites from granitic pegmatites for the Palaeoproterozoic accretion of $1.90-1.85 \mathrm{Ga}$ magmatic arcs to the Baltic Shield. Precambrian Research 67, 141-58.

RÄмÖ, T. 1990. Diabase dike swarms and silicic magmatism - evidence from the Proterozoic of Finland. In Mafic dikes and emplacement mechanisms (eds A. J. Parker, P. C. Rickwood and D. H. Tucker), pp. 185-99. Rotterdam: Balkema.

SKIÖLD, T. 1988. Implications of new U-Pb zircon chronology to early Proterozoic crustal accretion in northern Sweden. Precambrian Research 38, 147-64.

Skiöld, T., Öhlander, B., MarkKula, H., Widenfalk, L. \& Claesson, L.-A. 1993. Chronology of Proterozoic orogenic processes at the Archaean continental margin in northern Sweden. Precambrian Research 64, 225-38.

Sobral, J. 1913. Contributions to the geology of the Nordingrå region. Uppsala: Almqvist \& Wiksells Boktryckeri AB, $178 \mathrm{pp}$.

Solyom, Z., Lindevist, J.-E. \& Johansson, I. 1992. The geochemistry, genesis and geotectonic setting of Proterozoic dyke swarms in southern and central Sweden. Geologiska Föreningens $i$ Stockholm Förhandlingar 114, 47-65.

StreCKeisen, A. 1976. To each plutonic rock its proper name. Earth-Science Reviews 12, 1-33.

Sun, S. S. \& McDonough, W. F. 1989. Chemical and isotopic systematics of oceanic basalts; implications for mantle composition and processes. In Magmatism in the ocean basins (eds A. D. Saunders and M. J. Norry), pp. 313-45. Geological Society of London, Special Publication no. 42.

WAsströM, A. 1993. The Knaften granitoids of Västerbotten County, northern Sweden. In Radiometric dating results (ed. T. Lundqvist), pp. 60-4. Uppsala: Geological Survey of Sweden.

Welin, E., Christiansson, K. \& Kähr, A.-M. 1993. Isotopic investigation of metasedimentary and igneous rocks in the Palaeoproterozoic Bothnian Basin, central Sweden. Geologiska Föreningens $i$ Stockholm Förhandlingar 115, 285-96.

Welin, E. \& LUNDQvist, T. 1984. Isotopic investigation of the Nordingrå rapakivi massif, North-Central Sweden. Geologiska Föreningens i Stockholm Förhandlingar 106, 41-9.

Wood, D. A. 1979. A variably veined suboceanic upper mantle - genetic significance for mid-ocean ridge basalts from geochemical evidence. Geology 7, 499-503. 